University of Louisville

ThinkIR: The University of Louisville's Institutional Repository

Electronic Theses and Dissertations

$5-2004$

\title{
A human narrative in the metopes from the temple of Zeus at Olympia.
}

Amanda Beth Crecelius Ott 1980-

University of Louisville

Follow this and additional works at: https://ir.library.louisville.edu/etd

\section{Recommended Citation}

Ott, Amanda Beth Crecelius 1980-, "A human narrative in the metopes from the temple of Zeus at Olympia." (2004). Electronic Theses and Dissertations. Paper 1085.

https://doi.org/10.18297/etd/1085

This Master's Thesis is brought to you for free and open access by ThinkIR: The University of Louisville's Institutional Repository. It has been accepted for inclusion in Electronic Theses and Dissertations by an authorized administrator of ThinkIR: The University of Louisville's Institutional Repository. This title appears here courtesy of the author, who has retained all other copyrights. For more information, please contact thinkir@louisville.edu. 


\title{
A HUMAN NARRATIVE IN THE METOPES \\ FROM THE TEMPLE OF ZEUS AT OLYMPIA
}

\author{
By \\ Amanda Beth Crecelius Ott \\ B.A., Hanover College, 2002
}

\author{
A Thesis \\ Submitted to the Faculty of the \\ Graduate School of the University of Louisville \\ In Partial Fulfillment of the Requirements \\ For the Degree of
}

Masters of Arts

Department of Fine Arts

University of Louisville

Louisville, Kentucky

May 2004 
A HUMAN NARRATIVE IN THE METOPES

FROM THE TEMPLE OF ZEUS AT OLYMPIA

By

Amanda Beth Crecelius Ott

B.A., Hanover College, 2002

A Thesis Approved on

April 12, 2004

by the following Thesis Committee:

Thesis Director 


\title{
DEDICATION
}

This thesis is dedicated to my husband,

\author{
Joel Ott \\ and my parents, \\ Mr. Rick Crecelius \\ and \\ Mrs. Ann Crecelius
}

who has given me unending support throughout my educational career. 


\section{ACKNOWLEDGMENTS}

I would like to thank my professor, Dr. Linda Gigante, for her unending patience and guidance. I would also like to thank the other committee members, Dr. Robin Rhodes for his guidance at the start of this thesis and Dr. Ben Haufbauer, for his comments and assistance. I would also like to express my thanks to my husband, Joey, and parents for their continued patience and confidence. 


\section{ABSTRACT \\ A HUMAN NARRATIVE IN THE METOPES \\ FROM THE TEMPLE OF ZEUS AT OLYMPIA}

Amanda B. Crecelius Ott

May 8, 2004

Built during the Early Classical period, the Temple of Zeus at Olympia and its sculptural program presented many new ideas in Greek society. I will argue that the Temple, in particular its metopes depicting the twelve Labors of Herakles, exemplified the humanization of the Greek hero and illustrated the increasingly personal nature of Greek religion following the Persian War.

I will first discuss the history of Olympia and the Altis, especially in relation to the celebration of the Olympic Games. I will then describe the Temple of Zeus and its sculptural program. The sculptures, in particular the metopes, will be considered in the larger context of the important developments in Greek religion following the victories

over the Persians. I will argue that the metopes should be considered as one of the first architectural forms which connect man and gods in a personal, human way. 
TABLE OF CONTENTS

PAGE

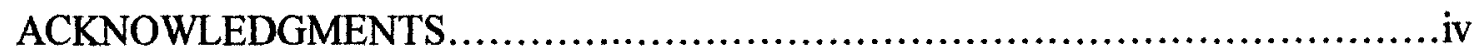

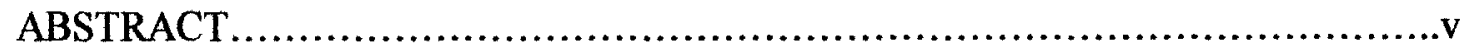

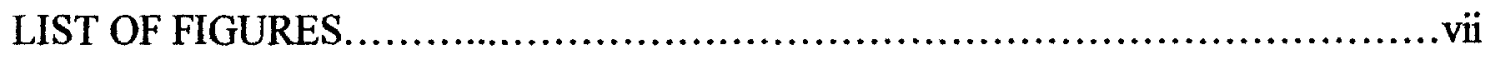

CHAPTER

I. INTRODUCTION ...................................................

II. THE SANCTUARY OF ZEUS AT OLYMPIA..........................3

III. THE SCULPTURAL PROGRAMS OF THE TEMPLE OF ZEUS.......13

IV. THE TEMPLE OF ZEUS IN ITS CULTURAL CONTEXT ..............29

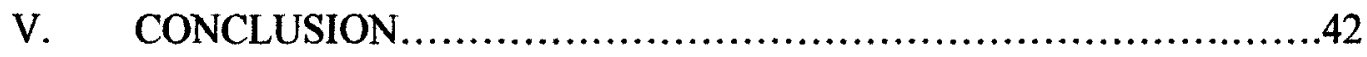

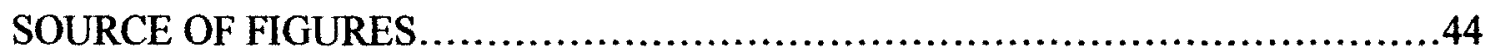

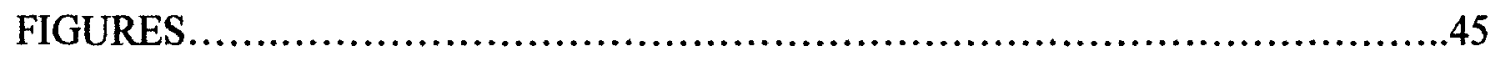

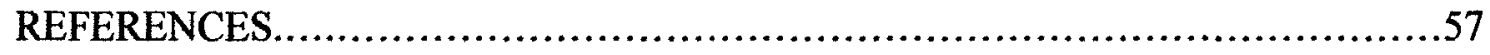

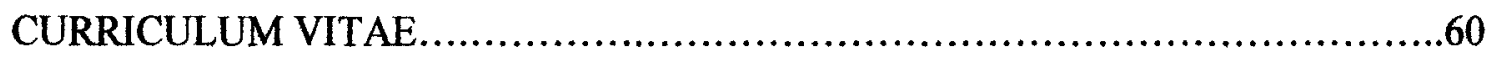




\section{LIST OF FIGURES}

FIGURES

PAGE

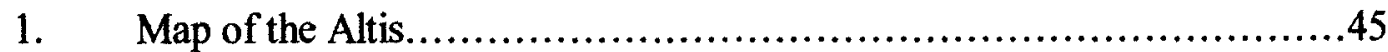

2. Plan of the Temple of Zeus...........................................46

3. Colossal Statue of Zeus..............................................

4. East and West Pediments of the Temple of Zeus..........................48

5. Twelve Metopes from the Temple of Zeus................................49

6. Nemean Lion Metope................................................50

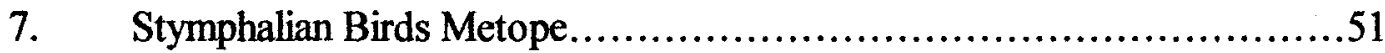

8. Herakles as an Archer on the Aphaia Temple at Aegina....................52

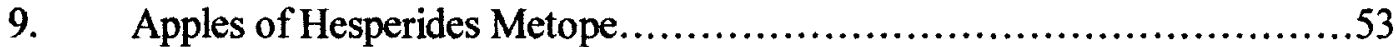

10. Metope of Herakles at Selinus on Temple C............................54

11. Attic Black-figure amphora from Vulci..............................55

12. Attic Red-figure Pelike from Cerveteri...............................56 


\section{A Human Narrative in the Metopes from the Temple of Zeus at Olympia INTRODUCTION}

In Early Classical Greece, a critical moment was embodied within an architectural form, the Temple of Zeus at Olympia. Built during a pivotal time in Greek history, the Temple of Zeus and its sculptural program presented many new ideas in Greek society. In this thesis I will argue that the Temple of Zeus, in particular its metopal depiction of Herakles, exemplified the humanization of the Greek hero and illustrated the increasingly personal nature of Greek religion following the Persian War.

The topic of this thesis came from a course in Greek architecture, offered by Professor Robin Rhodes in the spring semester of 2003. His book, Architecture and Meaning on the Athenian Acropolis, has been of great influence on the ideas presented in this thesis. Professor Rhodes' analysis of pedimental sculpture shed light on my discussion of the visual impact of the Olympia metopes. Professor Rhodes relates the movement of a religious procession through a building to the iconography of temple sculpture. From his idea of viewing the pediments came my interest in the viewing of the metopes at Olympia.

In this paper, I will first discuss the history of Olympia and the Altis especially in relation to the celebration of the Olympic Games. I will then describe the Temple of 
Zeus itself and, in particular, its sculptural program. Finally, the sculptures from the Temple of Zeus, in particular the metopes, will be considered in the larger context of the important developments in Greek religion following the victories over the Persians. I will argue that the metopes should be considered as one of the first architectural forms which connect man and gods in a personal and human way. 


\section{CHAPTER I}

\section{THE SANCTUARY OF ZEUS AT OLYMPIA}

In order to fully understand the experience of an ancient Greek viewing the Temple of Zeus, one must first understand the long history of this important Greek sanctuary. This chapter, which is limited to the period of the Temple's construction in the fifth century B.C., begins with a brief history of the site and a description of some of the buildings, the sacred sanctuary (Altis), and their functions. I will then focus on the Temple of Zeus, whose construction was the most important building program in the Early Classical period. Excavations of the site and Temple, which allowed archaeologists to understand more about Olympia, are also briefly considered.

\section{HISTORY OF OLYMPIA AND MT. KRONOS}

Built near the Hill of Kronos, the site of Olympia had a rich history in Greek culture (Fig. 1). The Olympian Altis on the side of Hill of Kronos denoted the area surrounding the sanctuary. Located in the Peloponnese, Olympia was accessible to most all of Greece, including the colonies in southern Italy and Sicily. The Sanctuary is located approximately a mile or two east of Pisa, with Elis about twenty miles north. With the Gulf of Corinth situated near Olympia, travel to Olympia by ship was uncomplicated and Olympia falls just a few miles from the coast. 
The earliest settlements at Olympia have been discovered dating as early as 2800 B.C. or the Early Helladic period. ${ }^{1}$ By the late Bronze Age, Olympia had been established as a sacred space, for archaeologists have excavated the ruins of six hairpin megarons built by the Mycenaeans. ${ }^{2}$ Little is known about these early structures compared to our knowledge of later sacred spaces. From the physical evidence of the megarons, archaeologists have proposed that the Altis at Olympia had been a sacred place or temenos since at least 1500 B.C. ${ }^{3}$ By the time the Temple of Zeus was built, the temenos had already been established as a sacred space for almost two thousand years.

By 1500 B.C., cults at Olympia included worship of several gods such as Kronos (the father of Zeus), Rhea, Gaia, Eileithyia, Themis, and Herakles. ${ }^{4}$ Evidence of these cults can be found in shrines, which where built for their worship below Mt. Kronos. ${ }^{5}$ Atop Mt. Kronos was the place where the Greeks worshipped Kronos. Survival of the Olympia Altis depended upon the belief that the land was sacred, belonging first and foremost to the gods rather than to the specific humans who inhabited the land.

Consequently, during war or unrest around Olympia, the Sanctuary was never destroyed or ravaged. ${ }^{6}$ As a result of this idea, several different gods and goddesses were accepted for worship on the Hill of Kronos.

By end of the seventh century B.C., the Altis was firmly established in Greek culture. Centuries of worship and activity at Olympia defined this Sanctuary as one of the most important in all of Greece.

\footnotetext{
${ }^{1}$ Anthanasia and Nicolaos Yalouris, Olympia: The Museum and The Sanctuary (Athens: Ekdotike Athenon S.A., 1991) 7.

${ }^{2}$ Ludwig Drees, Olympia: Gods, Artists, and Athletes (New York: Frederick A. Praeger, 1968) 6.

${ }^{3}$ Vincent Scully, The Earth, The Temple, and the Gods (New Haven:Yale University Press, 1979) 145

${ }^{4}$ Yalouris, 1991, 7.

${ }^{5}$ Manolis Andronicos, Olympia (Athens: Ekdotike Athenon S.A., 1995) 6.

${ }^{6}$ Ludwig Drees, Olympia (New York: Fredrick A. Praeger, 1964) 12.
} 


\section{MAPPING OUT OLYMPIA AND ITS BUILDINGS}

The Altis consisted of an area with three gates at the southeast, southwest, and northwest. Buildings concerned with religious rituals and practices were located within the boundaries of the Sanctuary, while buildings associated with athletes were built outside the boundary, a definite division between the sacred and the profane. Seven structures constituted the Sanctuary between the twelfth and seventh century B.C. Five of these structures were open-air altars devoted to specific gods where offerings were made. ${ }^{7}$ Zeus and the Mother of the Gods each had an altar while Hera possibly had three. ${ }^{8}$ These altars, clustered around the central northern part of the Sanctuary, were large, architectural constructs. When offerings, such as bulls and rams, were given to the gods, they were burnt on the altar; as a result, the ashes of the offerings continually built up making the altars extremely tall. Though scholars are unsure as to what the altars actually looked like, all reconstructions depict the Altar of Zeus as being several feet tall. The Greek traveler, Pausanias describes the Altar of Zeus in the second century C.E.: "It is built from the ash of the thighs of victims [animals] sacrificed to Zeus...the first step, which is called the outer circle, is a hundred and twenty-five feet round, and the circumference of the next step above it is thirty-two feet: the entire height of the altar is

as high as twenty-two feet." Pausanias describes the physicality of the altar itself, which consisted of a large base with steps on either side; ash offerings were piled on top of one another building up the altar. Steps were placed within the large mound to allow access

\footnotetext{
${ }^{7}$ Drees 6.

${ }^{8}$ Drees 6.

${ }^{9}$ Pausanias, Guide to Greece (Middlesex, England: Penguin Books, 1971) Book 5, Chapter 12, Line 8.
} 
to the highest point of the altar. Only men are allowed at the top of the altar to sacrifice the thighs of sacrificial victims. ${ }^{10}$

The funerary mound of Pelops or the Pelopion was established between the twelfth and seventh centuries B.C., which honored Pelops, the legendary hero. The Pelopion was located due west of the Altar of Zeus. A grotto, separate from the Pelopion, was also part of the Altis during this period. ${ }^{11}$ At this point in history, the sanctuary was still rather small, with few structures.

The next building to be added to the sanctuary was built in 600 B.C. This building, the Temple of Hera, stood in the northwest corner of the Sanctuary, north of the altar of Zeus and the Pelopion; it was the first temple built within the Altis, originally constructed of wood with several remodelings. Inside the Temple of Hera stood statues of both Hera and her husband Zeus. ${ }^{12}$ During the sixth century, other buildings were added to the temenos, including the Bouleuterion or the Council Hall, which was part of the Olympic Festival. The Prytaneion, or the place where the officials of the Sanctuary gathered, housed the sacred hearth and eternal flame of Olympia. ${ }^{13}$ Treasuries and a stadium were constructed during the sixth century B.C.

The fifth century B.C. was a time of tremendous building activity at Olympia. The Temple of Zeus was built in the southwest corner of the Altis, south of the Pelopion and the Altar of Zeus (fig. 2). A remodeling of the earlier stadium, new vapor baths, a hip-bath, and a swimming pool were also part of the building project during this time and

\footnotetext{
${ }^{10}$ Drees 21.

${ }^{11}$ Drees 6.

${ }^{12}$ Yalouris, 1991, 10.

${ }^{13}$ Yalouris, 1991, 14.
} 
were situated on the western part of the Sanctuary outside the boundaries of the Altis. ${ }^{14}$ A gilded statue of Nike sculpted by Paionios was commissioned during the later years of the century and was located directly in front of the Temple of Zeus.

\section{THE OLYMPIC GAMES AND RITUALS IN THE ALTIS}

Olympia was home to the Pan-Hellenic games in honor of Zeus, which were important to all Greek city-states. The festival, held every four years, placed Olympia in the forefront of Pan-Hellenic sanctuaries. The Greeks believed that the Olympics had been practiced in early times and were seen as a sort of ancestral worship. ${ }^{15}$ It has been theorized that the Olympic games originated from ancient burial rites in which games were held to honor the dead. ${ }^{16}$

Gymnasiums, baths, training facilities, and a stadium were some of the buildings built around the temenos for the Olympic Festival. When the Olympic Festival was not being celebrated, the population of Olympia included about six hundred living in the area. ${ }^{17}$ But the Olympics would have brought an audience of athletes, trainers, and spectators from all over Greek world sometimes numbering as many as forty thousand. ${ }^{18}$ The audience would have camped or stayed in inns around the temenos and would have generated a great deal of money for the economy of Olympia and nearby villages. ${ }^{19}$ The festival proved so important to Greece that, each year of the Olympiad, a truce was called during wars and all travelers were promised safe travel. ${ }^{20}$

\footnotetext{
${ }_{14}^{14}$ Judith Swaddling, The Ancient Olympic Games, (Austin: University of Texas Press, 1999) 34.

${ }^{15}$ Andronicos 7.

${ }^{16}$ Andronicos 12.

${ }^{17}$ Heinz Schobel, The Ancient Olympic Games (Princeton, NJ: Van Nostrand Company, Inc., 1965) 13.

${ }^{18}$ Drees 37-8.

${ }^{19}$ Drees 37-8.

${ }^{20}$ Swaddling 11.
} 
During the Olympic Festival, free, young, Greek athletes competed in several types of athletic games. A procession began the Olympic Festival from the Prytaneion. ${ }^{21}$ Athletes and their trainers then pledged an oath to Zeus at the Bouleuterion, the Council Hall next to the Temple of Zeus. ${ }^{22}$ In front of the Bouleuterion, a statue of Zeus Horkios, the god of oaths, marked the official site where athletes and trainers recited the oath before competing. A boar was sacrificed to Zeus Horkios and a pledge was recited over the animal's entrails. The athletes swore that they had not been bribed and had trained ten months prior to the Olympics. A group of judges and high officials, the Hellanodikai, presided over the games in order to insure fairness. ${ }^{23}$

The events took place over five days and included chariot racing, the pentathlon, foot races, wrestling, boxing, discus and javelin throwing, jumping and the famous pankration. ${ }^{24}$ The pankration was a combination of wrestling and boxing and was considered the most physical event. Philostratus, a third century A.D. writer, explained, "They bend ankles and twist arms and throw punches and jump on their opponents. All such practices are permitted in the pankration except for biting and gouging." ${ }^{25}$ The victor won when his competitor could no longer fight back. The presentation of prizes held in the Temple of Zeus, began with a procession to the Temple and included all the Olympic community throwing leaves and flowers on the victors. ${ }^{26}$ Prizes, which

\footnotetext{
${ }^{21}$ Swaddling 39.

${ }^{22}$ Swaddling 39.

${ }^{23}$ Andronicos 12

${ }^{24}$ Drees 67.

${ }^{25}$ Stephen G. Miller, Arete: Greek Sports from Ancient Sources, (Los Angeles: University of California Press, 1991) 38.

${ }^{26}$ Drees 85 .
} 
consisted of painted vases, olive wreaths, and ribbons of wool, were distributed to the athletes in the Temple. ${ }^{27}$

On non-festival days, worshippers made visits to the Sanctuary at Olympia to give offerings to the gods, such as honeycakes, wine, votive statues, or animal sacrifices. ${ }^{28}$ Offerings or sacrifices were made on the Altar of Zeus each day, but these were normally incense offerings, not animal sacrifices. ${ }^{29}$ The eternal flame of Hestia in the Prytaneum burnt all day and was also offered sacrifices. ${ }^{30}$ Public offerings were made every month at Olympia. ${ }^{31}$ Every altar received a daily sacrifice except for those of the chthonic gods, Gaia, Eileithyia, and Sosipolis; they received their sacrifices only at night. Kronos was the only exception, for he received a sacrifice only once a year atop the mountain named after him. ${ }^{32}$ Many people also worked in the Altis, including priests and officials who would have overseen these daily activities in the Altis. ${ }^{33}$

\section{THE TEMPLE OF ZEUS AND MODERN EXCAVATIONS}

In order to understand the experience of the ancient visitor to Olympia, we must consider one of the most important experiences - viewing the Temple of Zeus. The Temple of Zeus was a Doric structure, which was commissioned in 470-56 B.C. from the spoils of a local war between Elis and Pisa, a small village just east of Olympia. ${ }^{34}$ The spoils from Pisa and the surrounding area financed the construction of the Temple and its

\footnotetext{
${ }^{27}$ Nicolaos Yalouris, The Olympic Games in Ancient Greece, (Athens: Ekdotike Athenon S.A., 1982) 134.

${ }^{28}$ Hurwitt 35.

${ }^{29}$ Drees 22.

${ }^{30}$ Drees 22.

${ }^{31}$ Drees 23.

${ }^{32}$ Drees 23.

${ }^{33}$ Hurwitt 48.

${ }^{34}$ Bernard Ashmole, Architect and Sculptor in Classical Greece (New York: New York University Press, 1972) 3 .
} 
sculptural program. ${ }^{35}$ The Temple, built not only after the war between Pisa and Elis but also after the battle at Marathon, marked a new beginning for the Greek world. J.J. Pollitt explains the strict, geometric style of the temple as an expression of the new, rational order, which emerged out of the Persian War. ${ }^{36}$ To honor Zeus with a new temple for their grand Pan-Hellenic temenos and the Olympic Festival seemed only natural. In the years following the Persian War, Greek self-confidence and national unity were growing, but there was also a new sense of responsibility for the preservation of the Greek world.

A local architect, Libon of Elis, designed the Temple which originally stood sixtyeight feet in height, ninety-five feet in width, and measured two hundred and thirty feet in length. Pausanias described the Temple: "The style of workmanship of the temple is Doric, with a pillared portico around it: it is made of local stone." ${ }^{, 37}$ Though not innovative in its design, the Temple was a solid, traditional Doric temple. The eastern porch marked the entrance to the naos where the large statue of Zeus by Pheidias was added later in 435 B.C. (fig. 3). The western porch was the only entrance to the opisthodomus possibly where inscribed stelae were stored. ${ }^{38}$ While the exterior metopes were blank, the inner metopes above the two porches were decorated with reliefs depicting the Labors of Herakles. The building was made of local limestone covered with a layer of stucco to make the limestone resemble marble. The sculptors who worked on the sculptural program used over one hundred and thirty tons of Parian marbles. ${ }^{39}$

\footnotetext{
${ }^{35}$ Ashmole 4.

${ }^{36}$ J. J. Pollitt, Art and Experience in Classical Greece, (Cambridge, Massachusetts: Cambridge University Press: 1972), 42-3.

${ }^{37}$ Pausanias Book 5, Chapter 10, Line 2.

${ }^{38}$ Drees 116.

${ }^{39}$ Ashmole 18-20.
} 
Inside the Temple stood the large chryselephantine statue of Zeus, designed by Pheidias, which was placed in the naos approximately twenty-five years after the completion of the Temple. One of the Seven Wonders of the Ancient World, the statue portrayed Zeus seated on a throne. Decorated barriers divided the interior of the Temple into three sections. The colossal statue of Zeus will be discussed in greater detail in Chapter II.

For centuries Olympia was long forgotten, due to the silt that had covered the site from flooding. Renewed interest in the Altis came in the form of a letter in 1723 written by Bernard de Montfaucon, a French scholar, to the Bishop of Corfu, Cardinal Quirini. ${ }^{40}$ Montfaucon proposed that the soil at Olympia could be "full of monuments to the victors of Olympia and of statues, reliefs and inscriptions. ${ }^{, 41}$ Though Montfaucon was partially correct, no one acted on his request until 1766, when a British antiquarian and theologian, Richard Chandler, stumbled upon Mount Kronos and the ruins of a Doric temple, which proved to be the Temple of Zeus. ${ }^{42}$ Later French and British travelers visited the site, but it was not until after the liberation of Greece from Turkish rule in 1829 that the French organized an expedition to Olympia. The Morea Expedition, as it was called, investigated and discovered some of the sculptures from the Temple of Zeus, which were taken back to France and displayed in the Louvre. ${ }^{43}$ Topographical maps proved to be the most useful outcome of the expedition. By 1834, the newly formed Greek government stopped the French from excavating and turned the site over to German

\footnotetext{
${ }^{40}$ Schobel 109.

${ }^{41}$ Schobel 109.

${ }^{42}$ Swaddling 13.

${ }^{43}$ Schobel 110. Schobel explains that parts of the frieze from the Temple were taken back to the Louvre; yet, there is not an exterior frieze on the Temple unless he is referring to the triglyph metope frieze.
} 
archaeologist, Ernst Curtius. ${ }^{44}$ From about 1875 through1881, German archaeologists excavated the Temple of Zeus. ${ }^{45}$ Curtius and his team found the foundations of the Temple still intact though covered in soil. No columns or walls of the Temple of Zeus stand today, only the foundations and a few column drums. A museum was built at the Altis in which many artifacts found at the site, including the sculptures from the Temple, are exhibited. Excavations continue today, as archaeologists search for more information about the site.

The Altis and the Temple of Zeus had a rich past which all ancient Greeks considered part of their heritage. Every four years, all of Greece gathered to worship the king of the gods, Zeus. The focal point of their worship was the Temple of Zeus, with the Altar of Zeus also playing a major role in the religious rituals. It is important to keep this history in mind, when we consider what the ancient viewer experienced when viewing the sculptural program. In the next chapter, I will discuss the sculptural program of the Temple of Zeus and the myths which these works depict.

\footnotetext{
${ }^{44}$ Ernst Curtius, Excavation of Olympia (New York: 1875). Swaddling 16.

${ }^{45}$ Ashmole 8.
} 


\section{CHAPTER II}

\section{THE SCULPTURAL PROGRAM OF THE TEMPLE OF ZEUS}

The focus of this chapter is the sculptural program of the Temple of Zeus.

Following a brief discussion of Pheidias' statue, I will discuss the iconography of the sculptures in the pediments and examine the twelve metopes which illustrate the Labors of Herakles. This chapter will serve as a foundation for an examination of the significance of these sculptures, which will be discussed in Chapter Three.

\section{PHEIDIAS' STATUE OF ZEUS}

Located in the naos of the Temple of Zeus was the colossal gold and ivory statue of Zeus by Pheidias, usually dated c.432-30 B.C., and one of the Seven Wonders of the Ancient World. ${ }^{46}$ Pausanias describes the statue:

The god is sitting on the throne; he is made of gold and ivory. There is a wreath on his head like twigs and leaves of olive; in his right hand he is holding a Victory of gold and ivory with a ribbon and a wreath on her head; in the god's left hand is a staff in blossom with every kind of precious metal, and the bird perching on this staff is Zeus' eagle. The god's sandals are gold and so is his cloak, and the cloak is inlaid with animals and flowering lilies. The throne is finely worked with gold and gems, and with ebony and with ivory. There are animals painted on it and figures worked on it and four Victories dancing on the four feet of the throne. ${ }^{47}$

Pausanias goes on to explain that Zeus himself brought down a thunderbolt and struck the spot at which the statue stood. ${ }^{48}$ Pheidias depicted the King of the Olympian gods seated on a throne, holding a large gold and ivory Nike in his left hand and his scepter in the

\footnotetext{
${ }^{46}$ Yalouris, 1991, 17.

${ }^{47}$ Pausanias Book 5, Chapter 11, Line 1.

${ }^{48}$ Pausanias Book 5, Chapter 11, Line 9.
} 
other $^{49}$ It is believed the throne and base were decorated with mythological scenes featuring gods and heroes. ${ }^{50}$ The Eleans of Olympia must have believed that, along with the new magnificent Temple, Zeus also needed a great statue to honor him. Centuries later when Christianity became the major religion, the statue was pillaged and taken to Constantinople where it was destroyed in a fire in 476 A.D. ${ }^{51}$

\section{PEDIMENTS}

The sculptural program of the Temple of Zeus consisted of the pediment sculptures and the metopes. The subject matter of the east pediment is the local story of the chariot race between Pelops and King Oinomaos of Elis and is closely connected to the site of the Temple (fig. 4). Oinomaos, the King of Elis, had a beautiful daughter, Hippodamia, who was adored by many. In order to win Hippodamia's hand in marriage, a suitor had to defeat King Oinomaos in a chariot race. Yet no suitor was every able to defeat the King because his chariot was pulled by immortal horses. Pelops, a local young man, challenged the King to a chariot race. Pelops eventually killed the King by replacing the pins of his chariot with wax pins as was prophesizes by an oracle; consequently, Hippodamia and Pelops were married. Because Pelops cheated King Oinomaos, a curse was placed upon Pelops and his family for generations to come. Pelops, the grandson of Zeus, later became a local hero and was worshipped in the Altis Because of the deception of Pelops, this myth became an example to the Olympic athletes and trainers of the ultimate deception. Participants were reminded of deception and its consequences as they remembered the curse, which befell Pelops' descendants. Locally, the story of Pelops and Hippodamia would have been a common legend known

\footnotetext{
${ }^{49}$ Yalouris, 1991, 17.

${ }^{50}$ Yalouris, 1991, 17.

${ }^{51}$ Schobel 46.
} 
through the surrounding area of Olympia. Worshipped at Olympia at his mythical burial, Pelops was an important figure. Relating a local story with the Temple was a way to connect the surrounding area with the Temple.

This pediment has been reconstructed in the Olympia Museum. Though it is in a fragmentary state, the viewer can still get a sense of the figures' arrangement. Most of the limbs of the figures have disappeared or are broken. Several heads of figures are not preserved; yet, all the figures still give viewers a sense of what is taking place in the pediment. There is some ambiguity about whether King Oinomaos and the queen are on Zeus' left or the viewer's left. ${ }^{52}$ This is also the case with Pelops and Hippodamia because ancient writers, like Pausanias, were not specific in their description. ${ }^{53}$ Zeus stands in the center presiding over the protagonists before the beginning of the chariot race, with Pelops and Hippodamia on the viewer's left. ${ }^{54}$ The chariot of Pelops follows on the left side of Zeus next to Hippodamia. Behind the chariot, the charioteer sits with his hands holding out the reins of the horses. The seer of Pelops follows behind the charioteer. The figure located in the left hand corner of the pediment is the personification of the River Alpheios, which was near the sanctuary. On the right side of the pediment are King Oinomaos and Queen Sterope with the King's chariot and his charioteer Myrtilus at the reins. The seer of the King is seen behind the chariot, which is followed by the Queen's maid. In the corner of the pediment is the personification of the River Kladeos, another nearby river.

The five figures at the center of the pediment-Zeus, Pelops, Hippodamia, King Oinomaos, and Queen Sterope-stand frontal, while the remaining figures are seen in

\footnotetext{
${ }^{52}$ Ashmole 29.

${ }^{53}$ Pausanias Book 5, Chapter 10, Line 6.

${ }^{54}$ Ashmole 29.
} 
profile. J.J. Pollitt explores the element of drama in the east pediment, stating that the figures are fixed in thought as they ponder the imminent chariot race. ${ }^{55}$ None of the figures interacts with one another, while the facial features on all the figures of the pediment are stern. No emotions can be detected, only the tension, which occurs between the motionless figures.

In the west pediment of the Temple, the mythological battle between the Lapiths and Centaurs is depicted (fig. 4). According to the story, Peirithoos, a grandson of Zeus, married Deidameia and invited his neighbors, the Centaurs, to their wedding celebration. After becoming intoxicated, the Centaurs became violent with the Lapith women and a battle ensued. The Lapiths, protecting the women, slew the Centaurs and were victorious. Apollo, standing frontal towards the viewer at the apex of the pediment, looks out on the violent battle. On the left, Peirithoos advances towards the Centaur Eurytion who seizes the bride, Deidameia. Following Deidameia, a young boy struggles with a Centaur, while a woman, a Centaur, and a Lapith man follow on the left corner of the pediment. On the right, Theseus, the Attic hero and the groom's attendant, attacks a Centaur, which holds the bride's attendant. A mirror image of the threesome of Centaurs, Lapiths, and women can be seen in the left corner of the pediment as well as in the righthand corner.

In contrast to the east pediment, the west pediment is a flurry of action as the figures move around one another and are interlocked. The viewer is given the sense of two specific groups, the rational Lapiths and the irrational Centaurs. Emotion expressed on the creatures' faces runs high as the fight is depicted in great detail. However, the Lapiths have considerably less emotion then the Centaurs. This emotionless depiction of

\footnotetext{
${ }^{55}$ Pollitt 35.
} 
the Greeks relates the Greek ideal, which emphasized self-control. Figures are seen pulling at each other's hair and pushing each other away. The viewer is presented with a non-Greek people and a Greek tribe, who emulate the ideal of modesty and self-control. The Lapiths saved their women and their society in the same way the Greeks did during the Persian War. ${ }^{56}$ The centaurs were intended to symbolize the Persians during and after the Persian War.

\section{THE METOPES}

Like the metopes on most mainland temples, the exterior metopes of the Temple of Zeus are devoid of sculptural decoration (fig. 5). However, above each of the two inner porches there are six sculpted metopes, each measuring about five-foot square. The subject matter of these metopes is the Labors of Herakles. According to the myth, King Eurystheus ordered Herakles to perform the twelve labors. It is believed that Herakles performed these labors because of an oracle given to him at Delphi. ${ }^{57}$ As a result of Herakles' success, he was granted immorality after death, rose to Mt. Olympus, and was given the goddess Hebe as his wife. ${ }^{58}$ One might wonder why Herakles was depicted in such great detail on a Temple dedicated to Zeus. Not only was Herakles Zeus' son, but he was also believed to have founded the Olympic games in honor of his father. Herakles was born when Zeus disguised himself as Alkmeme's husband, Amphitryon, and tricked Alkmeme into lying with him, while she was waiting for her own husband. ${ }^{59}$

Pausanias discusses these metopes:

\footnotetext{
${ }^{56}$ Pollitt 35.

${ }^{57}$ Carpenter 119.

${ }^{58}$ Mark P.O. Morford and Robert J. Lenardon, Classical Mythology, (New York: Longman, 1985) 381385.

${ }^{59}$ Morford 385.
} 
Above the temple doors you see the hunting of the Arkadian boar, the labour with Diomedes the Thracian, the labour with the Geryon at Erytheia, and Herakles on the point of taking over Atlas's burden, and clearing the ground of dung for the Eleans; over the rear doors he is taking the Amazon's belt, and you see the story of the hind and the bull of Knossos and the Stymphalian birds and the manyheaded dragon and the lion of the Argolid. ${ }^{60}$

One cannot assume Pausanias is actually describing the order in which he viewed the metopes. Rather, one suspects that Pausanias is listing the labors of Herakles rather than describing the order in which the metopes appeared on the Temple. Bernard Ashmole's order of the metopes will be used in the following dicussion.

\section{The Nemean Lion}

This metope depicts what is often described as Herakles' first Labor - his fight with the Nemean Lion (fig. 6). King Eurystheus ordered Herakles to kill the Lion because the Lion was ravaging the countryside of Nemea. After slaying the Nemean Lion with a wooden club, Herakles brought the lion skin back to Eurystheus and, as a reward, was given the skin to wear. ${ }^{61}$ Consequently, Herakles is traditionally shown as carrying a club and wearing a lion's skin.

In this metope, Herakles is flanked by Athena on the left and Hermes on the right with the slain lion below the three. Little remains of this metope except the heads of both Herakles and Athena and the body of the lion. Herakles is depicted as a young man resting against the lion's back, exhausted from his battle. He stands with the club at his side and his right arm resting on his knee. In addition, some fragments of the limbs of both Herakles and Athena are extant, which help us understand exactly how the figures

\footnotetext{
${ }^{60}$ Pausanias Book 5, Chapter 10, Line 9. Along with Pausanias' description of the metopes, research was found in the following sources: John Boardman's Greek Sculpture, The Classical Period, Fifth Century Styles in Greek Sculpture written by Brunilde Ridgeway, Robin Osborne's Archaic \& Classical Greek Art, and Greek Sculpture: An Exploration written by Andrew Stewart.

${ }^{61}$ Morford 385.
} 
interacted. Athena and Hermes fill out the upper portion of this metope, as they look towards the youthful hero. Though not shown directly involved physically in this metope, both gods become a large part of the labors and the reason for Herakles' success. Some scholars even question whether or not Herakles is aware of their help at this point in the labors because there is no interaction between him and the gods and his gaze focuses on the Lion rather than the gods. ${ }^{62}$ One then wonders why the god and goddess are even present. Yet Athena and Hermes not only inspire Herakles, but also strengthen the weak, tired hero.

In this metope, the viewer witnesses a personal moment between a human being and two gods. Athena's gaze and her right hand emphasize and focus the viewer on the weary hero. She, the goddess of heroes, stands protectively over Herakles with her spear. Since Herakles is depicted without a beard, it is likely that he is not more than seventeen or eighteen. The age processing that occurs within the metopes could suggest the beginning of the metopes or also the evolution of the hero to maturity.

\section{The Hydra of Lerna}

In this metope, Herakles is shown battling the multiheaded Hydra of Lerna, a snaky monster with eight mortal heads and one immortal one. The sculptor has portrayed the moment when Herakles burned the Hydra's immortal head off with a torch. Consequently, the Hydra could no longer reproduce its heads and died. After killing the Hydra, Herakles dipped his arrows into the Hydra's poison, which would later prove to kill him. ${ }^{63}$

\footnotetext{
${ }^{62}$ Ashmole 66.

${ }^{63}$ Morford 388.
} 
The Hydra and Herakles fill out the composition and leave no room for any other objects within the space. The twisting necks of the Hydra spew from the right side of the metope, with its heads winding around the hero. Herakles stands on the left of the panel and the Hydra's many heads encircle his feet and ankles. The hero gazes intently at one of the serpent's heads whose jaws are open. The nude figure of Herakles is in profile, as one of the Hydra's heads appears to be about to bite his face. Herakles' beard suggests that the hero has matured since his slaying of the Nemean Lion.

This metope is in a poor state of preservation, and little remains of either Herakles or the Hydra. The main portions of Herakles' chest, some parts of his head and the center of the Hydra are fragmentary but are large enough to reconstruct the composition. The action of this metope contrasts with the Neamen Lion metope, in which Herakles is shown at rest. The violent activity in the Hydra metope creates a circular composition, with Herakles nearly enveloped by the monster's coils.

\section{The Stymphalian Birds}

In this Labor, Eurystheus sent Herakles to gather the Stymphalian Birds, which were ravaging the countryside around Stymphalus, a town in Arcadia ${ }^{64}$ Using Athena's castanets, he lured the birds out of the woods and then shot them down with his bow and arrow. In the metope, Athena is seated on a rock at the left and reaches for the birds, which Herakles presents to her (fig. 7). ${ }^{65}$ The hero, here bearded and mature, stands on the right holding out the birds in his hands.

Most of this metope is extant, with only parts of Herakles' legs and head missing. Herakles stands in three-quarter view, conveying a sense of confidence and strength. He

\footnotetext{
${ }^{64}$ Morford 388.

${ }^{65}$ Morford 388.
} 
holds something in his left hand, which is believed to be a bow. Others believe he could have possibly held a club, which is seen in several other metopes in this cycle. ${ }^{66}$ His pride can be seen in the almost frontal and authoritative pose of his body. Herakles appears to be fully aware of the help he has received from Athena. This is an intimate scene between Herakles and Athena in that the artist has shown goddess and man clearly interacting with one another. Not only did Athena help Herakles by giving him the castanets, but she also reaches towards the birds and looks towards him as he proudly gives the birds to her. This metope depicts the moment after the completion of the labor. With the birds in the center, the viewer's eye moves from Herakles to Athena and back again.

\section{The Cretan Bull}

Another labor performed by Herakles involved his capture of the Cretan Bull that was devastating Crete. ${ }^{67}$ This metope is nearly intact, with the exception of the legs and arms of Herakles and the Bull. A club is reconstructed in Herakles' right hand as he is ready to strike the Bull's head. He holds a rope in his other hand ready to tie up the Bull as soon as the animal is caught. Herakles stands in front of the bull as the bull wraps behind Herakles making the figures cross one another.

In contrast to the metope of the Stymphalian Birds, this metope is full of activity and movement. Herakles is at the height of this strenuous labor, as his muscular body stretches as long as the Bull's body. The opposing movement of both figures directs the viewer's eye back and forth between them. The Bull, up on his hind legs, lunges towards Herakles and turns back towards the hero. Nude and facing frontal with his head in

\footnotetext{
${ }^{66}$ Beth Cohen, "From Bowman to Clubman: Herakles and Olympia," Art Bulletin December 1994: 695715.

${ }^{67}$ Morford 387.
} 
profile view, Herakles is a mature man with a full beard and thick, muscular body. His dynamic figure dominates the entire composition.

\section{The Cerynean Hind}

This metope depicts Herakles wrestling with the Cerynean Hind, a golden-horned stag protected and beloved by Artemis. To satisfy Eurystheus and appease Artemis, Herakles injured the stag slightly and, when questioned by Artemis, blamed Eurystheus. ${ }^{68}$ This panel is poorly preserved, with only Herakles' hand on the Hind's muzzle, the Hind's chest, and parts of Herakles' thighs extant. Herakles stands with his right leg on the Hind's back quarters, lunges forward and pulls the Hind's head back. Both Herakles and the Hind are in profile. Herakles wears clothing, which is reconstructed as a pleated garment normally worn under armor. An example of this garment can be seen in the figure of Herakles as an archer on the east pediment of the Aphaia Temple at Aegina, which was sculpted around 480 B.C. (fig. 8). ${ }^{69}$ Herakles wears this garment in five of the twelve metopes. Scholars believe that this garment is a sort of waistcloth called a $\sin \alpha .^{70}$

The triangular composition of this metope displays a strong fully mature Herakles using all his strength to control the stag. This composition contrasts with the other eleven metopes. The panel of the metope is no longer full with sculpture; as a result, the viewer is intensely focused on the physicality of the struggle. As an intense moment ensues, Herakles overcomes the Hind.

\footnotetext{
${ }^{68}$ Morford 386.

${ }^{69}$ Anthony and H.W. Janson, History of Art, (Upper Saddle River, New Jersey: Prentice-Hall, Inc., 1991), 110.

${ }^{70}$ Ethel Abrahams, Ancient Greek Dress, (Chicago: Argonaut, Inc., 1964), 23.
} 


\section{The Girdle of the Amazon Queen}

This metope tells the story of Herakles retrieving the belt (girdle) of the Queen of the Amazons, Hippolyta. ${ }^{71}$ The sculptor has chosen to depict the moment after the fight between Herakles and the Queen. The hero towers above the Queen, with his club in his left hand and the girdle in his lowered right hand. Hippolyta, lying at his feet, leans on one elbow and looks up at Herakles. This metope is very fragmentary, as only a few pieces are preserved: the head of the Queen, the right leg of Herakles, the club, and other small fragments. It must be noted that, because of the fragmentary condition of this metope, a detailed reconstruction is difficult.

Scholars cannot determine exactly the emotion or the physical features of Herakles. What is clear from the fragments is that both figures are at rest. The action has already taken place and Herakles is possibly thinking about his own actions. He is shown here as totally dominant over what would have been to the Greeks a bizarre tribe of women who acted like men.

\section{The Erymanthian Boar}

The Erymanthian Boar was destroying the land around Mount Ermanthos; as a result, Eurystheus sent Herakles to capture the Boar alive. ${ }^{72}$ When Herakles brought the Boar to King Eurystheus, he cowered out of fear in a large pithos. In this metope, the viewer sees Herakles holding the Boar above his head while King Eurystheus, who hides in the pithos, reaches up towards the hero. This is the only metope is the only one in which King Eurystheus is depicted. All three figures are seen in profile view. Herakles and the Boar are on the left side of the panel, while the King is seen on the right side of

\footnotetext{
${ }^{71}$ Morford 389.

${ }^{72}$ Morford 387.
} 
the panel. The head of the Boar, the head of Herakles, Herakles' thighs, and most of the King are intact. The two figures and the Boar fill the space of the metope. Because a small piece of clothing appears on the thigh of Herakles, it is likely that he is dressed in the waistcloth, as seen in four other metopes.

With Eurystheus stretching upward and Herakles bent downward, the viewer's eye moves back and forth between the two figures. No emotion is visible on the faces of the figures, only urgency as Herakles lunges towards the King. This panel is one of the most active metopes in the cycle. A strong contrast between the hero's strength and superiority and King Eurystheus' fear is evident in the depiction of Herakles and the King. Herakles looms over Eurystheus, emphasizing dominance over the terrified King.

\section{The Mares of Diomedes}

The Mares of Diomedes were fleshing eating horses. Herakles eventually tamed the Mares but only after feeding them to their owner, Diomedes, a Thracian king. ${ }^{73}$ Fragments of the metope include the heads of Herakles and a Mare, its front hoof and tail, and Herakles' thighs. A few fragments of Herakles' arms are also extant. In this metope, Herakles leads the Mare with his left hand and holds his club in his right hand. His arms stretch the full width of the metope along with the length of the Mare. In profile view, the Mare rears up on her hind legs, as if Herakles is halting the Mare with one strong jerk. The hero's head is in profile view, but his body is frontal, emphasizing his massive, muscular body.

The viewer is presented with a composition similar to the one of the Cretan Bull in that Herakles stands in front of the Mare while her body wraps behind him. Herakles' intense gaze directs the viewer from him. The hero appears very determined, with his

\footnotetext{
${ }^{73}$ Morford 388.
} 
gaze focused intensely on the Mare as if self-assured of the victory at hand. Again, Herakles wears the waistcloth, which survives only in fragments.

\section{The Cattle of Geryon}

Herakles' next labor involved the capture of the cattle of Geryon, which involved his traveling to the island of Erythia to retrieve them. To achieve this labor, Herakles received help from Helios, the sun god, who gave him a golden bowl to sail across the sea. Once on the island, he killed Geryon, brought the cattle back to Eurystheus, and gave Helios back his golden cup. ${ }^{74}$ In this metope, Herakles stands in profile on the left and lunges forward with his arms above his head. With his club he strikes Geryon, whose triple body takes up most of the metope. One body of Geryon kneels, with his arm raised to protect his face and his shield blocking the rest of his body. Geryon's other bodies are below Herakles' legs as if already defeated. Their shields have fallen behind Geryon. The sculptor has chosen to depict the moment when Herakles slays the monster. Most of this metope is extant, with only the third head of Geryon and small fragments missing.

Seen in profile view, Herakles' figure is well developed, with defined muscles and powerful strength in an active pose. He again wears the waistcloth. The hero creates a powerful diagonal force, as he is ready to strike through the heads of the Geryon. Herakles' gaze also emphasizes the diagonal movement in the metope, as he looks down to the bowed head of the monster.

\section{The Apples of the Hesperides}

In this Labor, Eurystheus ordered Herakles to retrieve the golden apples. This Labor began with three daughters of the Night and a dragon who guarded the Garden of

\footnotetext{
${ }^{74}$ Morford 389.
} 
Hesperides in the far west. First, Herakles had to find Nereus, a sea god, who would disclose the location of the tree. He then asked Atlas, who had held the weight of the heavens on his shoulders, to get the apples for him. ${ }^{75}$ Once Atlas retrieved the apples from the Garden, the weight of the world was given back to him and Herakles took the apples back to Eurystheus. In this well-preserved metope, Atlas is seen on the right, handing Herakles the apples (Fig. 9). Herakles, with the help of Athena, holds the heavens on his shoulders. Athena, dressed in a peplos, stands frontal on the left and looks towards Herakles and Atlas. She effortlessly assists Herakles and the weight of the heaven. Herakles, in profile view, stands in the middle of the composition with his arms above his head. He holds the heavens on his shoulders, supported by a folded pillow probably given to him by Athena. Atlas stands at the right, with his hands outstretched, presenting Herakles the apples. While the three figures create strong vertical, their arms connect the figures to one another. Atlas stands in a relaxed pose in contrast to Herakles, who supports his weight on straight legs. The viewer's eye moves from Athena and her raised arm, to Herakles' arm and face, to Atlas' outstretched arms.

The focus of this metope is the intimate relationship between Athena, the goddess of heroes, and Herakles. He could not possibly support the weight of the heavens on his own, nor could he complete this labor without the goddess' help. The two are positioned in close proximity to one another, almost appearing to touch. Athena is here Herakles' personal protector.

\section{Cerberus, The Hound of Hell}

Herakles was ordered by Eurystheus to go to Hades to retrieve Cerberus. With the guidance of Hermes and Athena, Herakles found the Hound of Hell, brought him to

\footnotetext{
${ }^{75}$ Morford 391.
} 
King Eurystheus, and then returned Cerberus to Hades. ${ }^{76}$ In this metope, Herakles, standing on the left and wearing a waistcloth, pulls Cerberus by a rope. Cerberus crouches in the lower right corner of the metope, with only his head visible. He gazes up at Herakles with a ferocious look on his face. Hermes, standing in the background, looks on. Herakles and Cerberus are almost completely intact, but only the foot of Hermes is extant.

Herakles' downward gaze and the rope direct the viewer's eye to the focus of the labor, Cerberus. The placement of the rope and the angle of Herakles' body create a sharp, diagonal composition. Both Herakles and Hermes are seen in frontal view, but Herakles turns his head to look at Cerberus.

\section{The Augean Stables}

The Augean Stables, which housed a huge herd of cattle, had never been cleaned until Herakles was ordered by King Eurystheus to clean them. With the help of Athena, he dug around the foundation of the Stables to let the Rivers Alpheus and Peneus flow through them. ${ }^{77}$ Herakles, on the left, raises the shovel, as Athena points out to the place where the foundation of the Stables should be broken. Almost all of this metope still exists; only the body of Herakles is reconstructed. The sculptor has depicted the moment just before the force of water pushed through the Stables. Two sharp diagonals run across the middle of the metope, the shovel of Herakles and the spear of Athena.

Both Athena and Herakles face frontal towards the viewer, but they both look left, towards the foundation. Athena wears a helmet and peplos and Herakles is heroically nude. While Herakles is determined, with no emotion on his face, Athena advises him

\footnotetext{
${ }^{76}$ Morford 393.

${ }^{77}$ Morford 387.
} 
what to do. Herakles and Athena's relationship in this metope is authoritative, with Athena the authority. The strict and firm diagonal of her spear and arm, along with her helmet, reinforces this sense of authority and determination.

All these metopes deal directly with the relationship between Herakles and the gods, in particular Athena. This has to be taken into account when exploring the effect these metopes would have had on the ancient viewer. One can see that, in most of the metopes, a personal relationship exists between Herakles and Athena. By placing these depictions on this important Temple, the sculptors intended that the ancient viewer be affected. One must keep in mind the sculptural program of the Temple, its impact on the viewer, and the cultural context of the Temple, in order to fully appreciate the significance of this building in the cultural context of the Early Classical period. 


\section{CHAPTER III}

\section{THE TEMPLE OF ZEUS IN ITS CULTURAL CONTEXT}

During the construction of the Temple of Zeus, several aspects of Greek society were evolving which would shape the future of Greek culture. The pivotal period before and during the building of the Temple saw religion, literature, and art change dramatically, but the most important influence was the Greeks' victory over the Persians in early conflicts of the war (490-480 B.C.). These specific aspects of Greek culture religion, the Persian War, literature, and art - and their evolution will be explored in this chapter. My discussion will relate these cultural aspects specifically to the metopes from the Temple of Zeus. One will see the humanization of Herakles in these depictions; consequently, the viewer establishes a more personal connection with Herakles. A short history of Archaic, violent depictions of Herakles will verify the change in metopal sculpture.

\section{THE IMPACT OF THE PERSIAN WAR}

In the minds of the Greeks, the victory over the Persians at Marathon and Salamis preserved the Greek people, and also the Greek way of life. The influence of the Persian War on Greek culture had a major impact on the future of Greece. During the Persian War, a sense of a Panhellenic Greece or unity existed all over Greece because of threats 
from the Persians. ${ }^{78}$ As a consequence, alliances, such as the Delian League, were formed. ${ }^{79}$ Though this Greek unity was short lived, the Temple of Zeus was built during the period immediately following the Persian War and this defined change in culture. J. J. Pollitt comments on the mentality of the Greeks at this time: "The defeat of the Persians had seemed a triumph of order and reasoned individual discipline over an irrational darkness." ${ }^{80}$ The Temple was the embodiment of this 'triumph of order.' In the metopes, Herakles essentially establishes order over the countryside of the Peloponnesus by defeating his adversaries. Throughout Greek history, the definition of the "other" was defined as any group of people other than the Hellenes. During the Persian War, the idea of the "other" was re-emphasized with the intrusion of the Persians into the Greek world. Essentially, the Greeks considered themselves to be rational, thoughtful human beings with the ability to possess self-control while any other group of people, such as the Persians, was irrational, chaotic and unable to control themselves. ${ }^{81}$

An example of the idea of the "other" can be seen on the west pediment of the Temple with the battle between the Lapiths and the Centaurs. The Centaurs could not control themselves and overindulged in wine. With their drunkenness came chaos. If the Centaurs had been like the Lapiths, the Centaurs would not have overindulged nor would there have been a fight because the Greeks would have enough self-control not to proposition the Lapith women. The emotionless faces of the Lapiths illustrate the idea of self-control, as the women being attacked appear with no emotion on their faces. The metopes from the Temple also explore the idea of the "other" with the subject matter of

\footnotetext{
${ }^{78}$ Stanley M. Burstein, Walter Donlan, Sarah B. Pomeroy, and Jennifer Tolbert Roberts, Ancient Greece: A Political, Social, and Cultural History, (New York: Oxford University Press, 1999) 201.

${ }^{79}$ Burstein 201.

${ }^{80}$ Pollitt 32.

${ }^{81}$ Stanley M Burstien 197-199.
} 
Herakles, the Greek hero, overcoming several non-Greeks, such as the Queen of the Amazons. These women were seen as irrational and chaotic, for they dressed and fought like men. In the Greek world, natural order placed women in the oikos, not on the battlefield. The Persian War re-emphasized the Greeks' perspective of themselves relative to other groups of people.

Jon D. Mikalson, in Athenian Popular Religion, comments on the individual in Greek society, explaining that the individual had concerns which were distinct from the state. ${ }^{82}$ Mikalson considers the notion of the individual through the religious prayers written by Xenophon (428-354 B.C.), who prayed for his own health, strength of body, honor in the city, goodwill among friends, safety in war, and honorable wealth. ${ }^{83}$ Individuality might well have thrived within the social norms during the period after the Persian War. In the metopes at Olympia, Herakles is not just a hero but an individual striving to achieve feats of bravery. Greek men were able to relate to Herakles' almost unachievable feats because they had faced similar dangers at Marathon and Salamis. Though outnumbered, the Greeks overcame the Persians. The way the sculptors chose to depict Herakles also promoted the idea of the individual to the viewer. In the metopes, figures are not depicted frontal and stiff staring at the viewer, but rather, struggle and fight intertwining with one another. Herakles is frequently depicted in a foreshortened pose and the artists portray him as naturalistically as possible. This treatment relates Herakles to the viewer as being more human because this is how humans are viewed within the world.

\footnotetext{
${ }^{82}$ Jon D. Mikalson, Athenian Popular Culture, (Chapel Hill: The University of North Carolina Press, 1983), 22.

${ }^{83}$ Mikalson 22.
} 
In Greek society, an individual's emotions consisted of two distinct parts- the ethos and pathos. Ethos was considered a man's character by inheritance, habit, and selfdiscipline, whereas pathos was a man's natural reaction to his experiences within the world. ${ }^{84}$ During the Early Classical Period, artists began experimenting with the depiction of these emotional forces. Pollitt explains that the metopes of the Temple of Zeus are among the greatest expressions of ethos and pathos. ${ }^{85}$ The viewer is shown a tired, triumphant man who endures the Twelve Labors. ${ }^{86}$ Herakles also is portrayed very emotional in some of the metopes. In the metope of the Nemean Lion, Herakles rests in exhaustion on the Lion, which he just defeated. Another important Greek idea was arête, which refers to a man's excellence in battle and virtue. Men were driven to be their very best for the polis. ${ }^{87}$ In the Olympic metopes, Herakles exhibits arête, as he battles adversaries who threatens his life and the lives of people in the Peloponnesus.

Though the polis took precedence over the individual, the individual was essential to the success of every Greek polis. Young boys were encouraged and expected to be the best they could be. All upper class young men traditionally received a certain education of scholarship, but also of athletic achievement. With competition came the idea that one individual could be superior to another. Yet one must remember that individuality was only encouraged if it was part of the social norms or rational order in society. This achievement of the individual is explored in the depiction of Herakles in the Olympia metopes. He is an individual who fights to better the Peloponnesus, by saving the countryside from menacing adversaries.

\footnotetext{
${ }^{84}$ Pollitt 43.

${ }^{85}$ Pollitt 50.

${ }^{86}$ Pollitt 50.

${ }^{87}$ Stanley Burstein 60-1.
} 
The Greek perspective of the natural order of the world was also affected by the outcome of the Persian War. Earlier, the order of the world had been explained in the context of gods and goddesses. After the War, rational thought assumed a dominant role in literature. Consequently, problems and solutions were explained through rational thought and the order of nature, rather than gods. ${ }^{88}$ In defeating the Persians, the Greeks now solved problems for themselves with help from the gods, rather than relying only on them. ${ }^{89}$ This change in the natural order of the Greeks' world can also be associated with changes in their religious beliefs. Again, this is seen in the metopes at Olympia.

Herakles, though ordered by King Eurystheus to accomplish the labors, chose to solve the labors himself and dealt with his adversaries through his own ingenuity. Though Athena and Hermes helped, Herakles struggled through the labors alone.

\section{CHANGES IN RELIGIOUS BELIEFS}

The Greeks in all periods of their culture practiced polytheism, rituals of animal and liquid offerings, and honored their gods in religious festivals. During the Archaic Age, belief in the gods and goddesses explained the natural order of life, which man had no way of understanding. ${ }^{90}$ Daily threats, such as wars or disease, were explained as signs sent from a god who looked down upon the people unfavorably. Many times in Greek history, writers explained that the gods must have been upset with a certain group of people to bring these sorts of problems on them. This religion was a fear-inspiring, omnipotent religion in which humans were at the mercy of the gods and goddesses. The Greeks had no concept that they could control their own fate.

\footnotetext{
${ }^{88}$ Walter Burkert, Greek Religion, (Cambridge: Harvard University Press, 1985) 305.

${ }^{89}$ Burkert 306.

${ }^{90}$ Scully 145.
} 
After the Persian War, the Greeks began asking different questions about themselves, their world, and the gods. While Archaic religion had explored the behaviors of man and the institutions themselves, during the beginning of the Classical era and the Temple of Zeus, the Greeks considered the ideas of the individual and his place in society. ${ }^{91}$ Vincent Scully explains this new concept in religion: "The great conflicts would now take place, not between men and external things, but within men themselves as they sought perhaps to avoid their fate of knowing, and then finally struggled upward toward the knowledge which could alone reveal their part in the whole of things." ${ }^{, 92}$ Questions about man and his place in the universe were concepts with which the Greeks began to struggle. Herakles also struggled with these same issues in his quest to accomplish the twelve labors. Why was he ordered to complete the twelve labors? What was Herakles doing for the Peloponnesus? Herakles became the role model for bravery and courage.

For centuries a cult of Herakles had existed in Greece. Along with the general evolution of Greek religion, the worship of heroes also changed. Early Herakles cults emphasized the violent physical labors, but later, during the Early Classical period, Herakles came to be seen as a sort of spiritual leader. Walter Burkert characterizes Herakles as "a prototype of the ruler who by virtue of his divine legitimation acts in an irresistible way for the good of mankind and finds his fulfillment among gods." ${ }^{93}$ These cults also began to see Herakles as a "model for the common man who may hope that after a life of drudgery, and through that very life, he too may enter into the company of

\footnotetext{
${ }^{91}$ Burkert 305.

${ }^{92}$ Scully 145.

${ }^{93}$ Burkert 211.
} 
the gods.. ${ }^{94}$ In the Olympia metopes, these concepts took physical form. Exhausted in the Nemean Lion metope, Herakles begins his drudgery, which the common man would have endured all his life through hard daily labor. Not only did the viewer get a sense of the hardships which Herakles endured, he saw that Herakles fought through the hardships and received his reward. In other words, Herakles became the Greeks' personal connection to the gods. Depicted on a temple honoring Zeus, Herakles was as close to a common man as would be depicted on a temple. With the changes in religion, Herakles became the ideal for which men strove.

\section{LITERARY VIEWS}

As the concept of Herakles evolved in the Classical period, so too did the literature referring to Herakles. Archaic Greek literature had emphasized the violent and heroic nature of Herakles; the labors while violent, were necessary. Characteristics of heroes of the Archaic past included the reality of death, love of life, a violent death, and an appetite for food, wine, and women. ${ }^{95}$ Herakles knew he would eventually die, loved life on earth, was killed by his own poisoned arrow, loved women and food, and was strong enough to accomplish unimaginable tasks. Therefore, the physicality of Herakles was elevated and venerated in earlier times.

Later, during the Early Classical period, writers explored the human side of Herakles and all the beneficial good he accomplished for the Greeks. Herakles acquired the characteristic of understanding through all his complicated and frustrating trials. He was also seen as helping humans understand abstract ideas, such as time and fate. ${ }^{96}$ For

\footnotetext{
${ }^{94}$ Burkert 211.

${ }^{95}$ Burkert 210.

${ }^{96}$ Jaimee Pugliese Ulhenbrock, Herakles Passage of the Hero Through Thousand Years of Classical Art, (New Rochelle, New York: Aristide D. Caratzas, 1986) 33.
} 
example, Pindar, the fifth-century poet, characterized Herakles as devoted to his labors for the good of mankind, rather than enjoying the violent nature of the labors. ${ }^{97}$ The poet praised him for becoming a hero and achieving immortality for his services. Another fifth-century poet, Baccylides, wrote about Herakles and his meeting with Meleager in Hades. Baccylides described their meeting: "They say that then and then alone, tears came to the eyes of Amphitryon's fearless son [Herakles], as he pities the fate of that sorrowful man [Meleager]." ${ }^{98}$ Similar to the exhausted Herakles in the Lion of Nemean metope, the Herakles depicted in this poem shows a human quality of sorrow and pain by crying for Meleager. In the Archaic context, Herakles would have never been portrayed as a man with a human weakness for tears. Baccylides stressed that Herakles overcame trials and struggled in life with action, just as the Greeks defeated the Persians with action. ${ }^{99}$ The viewer looking at the Olympic metopes would not strive to emulate the violent nature of Herakles; rather he wished to emulate the virtue or arete which Herakles displayed enduring the Labors.

Dramas were another source of influence in Greek culture. The only complete trilogy to have survived, Aeschylus' Orestia, dates to 458 B.C., around the time of the construction of the Temple of Zeus. ${ }^{100}$ These plays deal directly with the relationship between man and the gods, a subject similar to the labors of Herakles. ${ }^{101}$ The basic message of the Trilogy is the evolution of society or the end of a violent, oppressive period and the beginning of a new liberating era similar to the symbolic meaning Pollitt

\footnotetext{
${ }^{97}$ Rainer Volkommer, Herakles in the Art of Classical Greece, (Oxford: Oxford University of Committee for Archaeology, 1988) 79.

${ }_{98}$ Volkommer 79.

${ }^{99}$ Volkommer 79.

${ }^{100}$ Peter Connolly, The Ancient City: Life in Classical Athens and Rome, (Oxford: Oxford University Press, 1998) 95.

${ }^{101}$ Pollitt 27.
} 
gives the Temple of Zeus. ${ }^{102}$ Seeing these plays would have been an experience for the whole community and many Greeks would have been familiar with the trilogy. ${ }^{103}$ Aeschylus seems to have echoed within a play the evolution that was actually occurring within his own society. Not only does this trilogy describe the change in religion, but it also deals with the changes occurring within the art of the Temple's period.

\section{VIEWING THE METOPES AT OLYMPIA}

An important shift in art occurred during the mid-fifth century B.C. The same awe and fear-inspiring characteristics of Greek religion can be seen in the depictions of Herakles in Archaic art. An Attic black-figure Tyrrhenian amphora from Vulci dated 560 B.C., depicts Herakles and the Queen of the Amazons (fig. 11) ${ }^{104}$ Herakles is in the middle left grabbing the wrist of the Queen, who struggles to flee to the right. Soldiers on either side of Herakles fight other Amazons around the sides of the amphora. Though not portrayed frontal, which hardly ever occurs in early vase painting, the figures are depicted violent and confrontational to each other. Herakles' muscles are geometric shapes and his eye is seen as the focus of the facial features. Brutality is a focal point, as Herakles raises his sword over the Amazon and grabs her wrist.

The shift in art is also visible when comparing metopes from earlier temples to those of the Temple of Zeus. Metopes from Archaic temples in western Greece depict gods and heroes similar to the attitudes in Archaic religion. For example, one of the metopes from Temple C at Selinus, dated to 550 B.C., depicts Herakles capturing the Geryons (fig. 10). ${ }^{105}$ Herakles is shown in the middle of the metope with his head facing

\footnotetext{
${ }^{102}$ Burstein 225.

${ }^{103}$ Pollitt 27.

${ }^{104}$ T.H. Carpenter, Art and Myth in Ancient Greece, (London: Thames and Hudson, 1991) 144.

${ }^{105}$ Stewart 84-87.
} 
forward. He holds two of the Geryons upside down on his shoulders. Each is facing forward with arms crossed and legs twisted around Herakles' shoulders.

The viewer is not given the naturalistic, struggling and personal Herakles as seen in the later metopes of the Temple of Zeus. Rather, this Archaic Herakles stands emblematically erect and uninvolved with the Geryons. He looks forward and stares out at the viewer along with the Geryons. The figures are seen with large oval eyes, which are the focus of the figures' faces. Fear and awe surround the depiction of Herakles, rather than the struggling human Herakles at Olympia. In addition, the stylized treatment of the figures makes it difficult for the viewer to relate to them. The muscles are geometric shapes rather than smooth, strong muscles seeing almost as inhuman. The hair of the figures resembles little beads, rather than locks of hair. Also emphasized at Selinus are the physicality and brutality of the action, as Herakles holds the two Geryons on his shoulders. At Olympia, viewers see the labor taking place as Herakles struggles to overcome the Geryons. All these characteristics emphasize the beliefs of Archaic religion rather than the art and the individual, which appears in the Classical period at the Olympia metope of Geryon. Herakles, in profile view, is in the middle of his fight with Geryon. Though two of the three heads have been killed, Herakles has not yet won the battle. The metope emphasizes his struggle with, rather than his dominance over Geryon. Changes in Greek culture following the Persian War affected the way in which art was created and viewed. Though scholars today cannot fully grasp the minds or beliefs of the sculptors and the viewers of Classical Greece, they can use the evidence that exists today to get a better understanding of how the ancient sculptors and viewers were affected by their environment. For the ancient viewer, seeing the pediments and the 
metopes must have been a very different experience. The first thing one must keep in mind is that the pediments were bigger and much farther away from the viewer than the metopes. Though the ancient Greek would have been very familiar with both stories depicted on the Temple pediments, placing oneself in the story of Pelops and Hippodamia or the Centauromachy would be unthinkable to the ancient viewer. When viewing the metopes at Olympia, on the other hand, Herakles is relatable and the panels read as a narrative to the viewer. This human side of Herakles comes from two characteristics of the metopes - the narrative quality and the physicality of the figures.

When discussing the narrative quality of the metopes, we must remember that all the labors of Herakles are depicted on the Temple. A cycle or narrative story is presented. Older metopes gave viewers one or even two labors, but the artists at Olympia chose to depict the complete story of the Twelve Labors. By exploring all the Labors, the viewer no longer had to recall by memory the other Labors not depicted. At the same time, the viewer would have become an active part of the metopes, as he observes Herakles complete the actions within the metopes.

In the Olympia metopes, Herakles is shown less confrontational with respect to the viewer and more involved in his own actions. The compositions also flow from one another so that the viewer was able to read the metopes like a story. In some of the metopes, even though the hero is not physically engaged in a Labor, Herakles is emotionally involved. For example, in the metope of the Nemean Lion, the action is complete and the hero looks to the lion slain on the ground and expresses exhaustion.

The emphasis of the Olympia metopes is more on the narrative and the struggle of the Twelve Labors and less on the hero's physical dominance. With the aging of 
Herakles, all aged viewers ranging from young boys to seasoned Greek men can relate to the hero. Herakles' journey can be a model for all Greek males. Seen as a youth, the viewer could see the development which occurs in the metopes and re-emphasized the sense of narrative.

The Olympia metopes are also related to the new relationship between man and the gods following the Persian War. By depicting Hermes and Athena helping Herakles in five of the twelve labors, the sculptors showed Herakles as not isolated in his struggles; in fact, he has a personal and intimate relationship with Athena as she assists him. The viewer also became aware of the omnipresence of the gods and could relate to this relationship, which Herakles is shown to have. Herakles' role in Greek religion made him more human. Since Herakles had a god for a father and a mortal mother, he could understand both the experience of struggle and the experience of being a demi-god. As a result, he held a special place no one else in Greek myth held and connected humans to their immortal gods.

The physicality of Herakles in the Olympia metopes also prompted the viewer to relate to the image of Herakles. By losing the bulky and geometric characteristics of the Archaic Period, Herakles at Olympia resembles the figure of an average Hellene or even the muscular figure of an athlete. This naturalistic treatment of the hero can also be seen in contemporary vase painting. An Attic red-figure pelike from Cerveteri dated to 470 B.C. depicts Herakles similar to the way in which he is shown on the Olympian metopes (fig. 12). ${ }^{106}$ Herakles stands on the left, next to Geras (old age) on the right and resembles any Greek man holding a conversation with another man. Herakles is just

${ }^{106}$ Carpenter 154. 
another man confronting the inevitability of aging. Violence is not the focal point, rather the relationship between the two men become the central issue.

We must also address the issue of the accessibility of the metopes at Olympia. Because of the location of the Temple in the Altis, athletes and trainers would have passed by the Temple after taking their oath at the statue of Zeus Horkios. During the prize ceremony, spectators, athletes, and trainers would have been inside the building. ${ }^{107}$ Consequently, all would have had to pass beneath the metopes. Priest and priestesses would also have been in constant contact with the metopes. The metopes could also been seen from outside of the Temple; therefore close proximity is not absolutely necessary. With this close relationship between the Temple and the Olympic Festival, viewers must have had access to the Temple.

By viewing the architecture and sculpture of the Olympia Temple in its environment, the ancient viewer had a unique experience. Pheidias' statue of Zeus conveyed the importance of Zeus and his power, while the west pediment of the Temple reminded the viewer of the triumph over order in a world where life was unstable and chaotic. The metopes also conveyed the same triumph of order, but showed a man triumphant. As a result, the ancient viewer would have been able to connect with Greek religion in a personal way.

${ }^{107}$ Drees 85. 


\section{CONCLUSION}

After studying the metopes of the Temple of Zeus, there are several questions, which arose and could not be explored in this paper. From this thesis, several issues about the metopes or the objects themselves came about after research. Two issues arose which I believe would be important to the future scholarship of the metopes. The arrangement of the metopes on the Temple are still in question today and further study is critical to understanding the metopes in their context. Another issue is the dress of Herakles. As I noted in this thesis, the hero is dressed in five of the twelve and nude in the other remaining metopes. The question becomes why is he depicted nude in some and clothed in others.

When discussing the arrangement of the metopes, there are several ideas to keep in mind. Six metopes were displayed on each end of the Temple. The presence of gods, the active versus the passive Herakles, and the visual movement of the metope are only some of the ideas one could use to organize the metopes on the Temple itself. For example, four metopes depicted Herakles with Athena which could help us to relate those four metopes to the four corners or to the centers of each side of the Temple. The Augean Stables metope draws the viewer's eye to the left, which possibly suggests that the metope could have been a corner piece. The Hind metope, with its triangular composition, could have been a center metope where the viewer's eye could be pulled either way in 'reading' the metopes. 
Herakles' dress also becomes problematic when studying the metopes. The question arises why is he dressed in some and nude in others. His dress could be associated with the Labor which he is involved in. The location of the Labor could also affect the dress which Herakles is depicted in the metope. One asks the question is the reconstruction of the dress correct in some of the metopes. These are just two of many other issues, which surfaced when exploring the metopes of the Temple of Zeus. Understanding the metopes more as objects can also help scholars in understanding in greater detail the cultural context of these metopes and ultimately learn more about the artists who carved then and the people who viewed them. 


\section{Source of Figures}

Figure 1: Ludwig Drees, Olympia: Gods, Artists, and Athletes

Figure 2: Visual Resource Center at the University of Louisville

Figure 3: Visual Resource Center at the University of Louisville

Figure 4: Bernard Ashmole, Architect and Sculptor in Classical Greece

Figure 5: Bernard Ashmole, Architect and Sculptor in Classical Greece

Figure 6: Visual Resource Center at the University of Louisville

Figure 7: Visual Resource Center at the University of Louisville

Figure 8: Visual Resource Center at the University of Louisville

Figure 9: Visual Resource Center at the University of Louisville

Figure 10: Visual Resource Center at the University of Louisville

Figure 11: T.H. Carpenter, Art and Myth in Ancient Greece

Figure 12: T.H. Carpenter, Art and Myth in Ancient Greece 


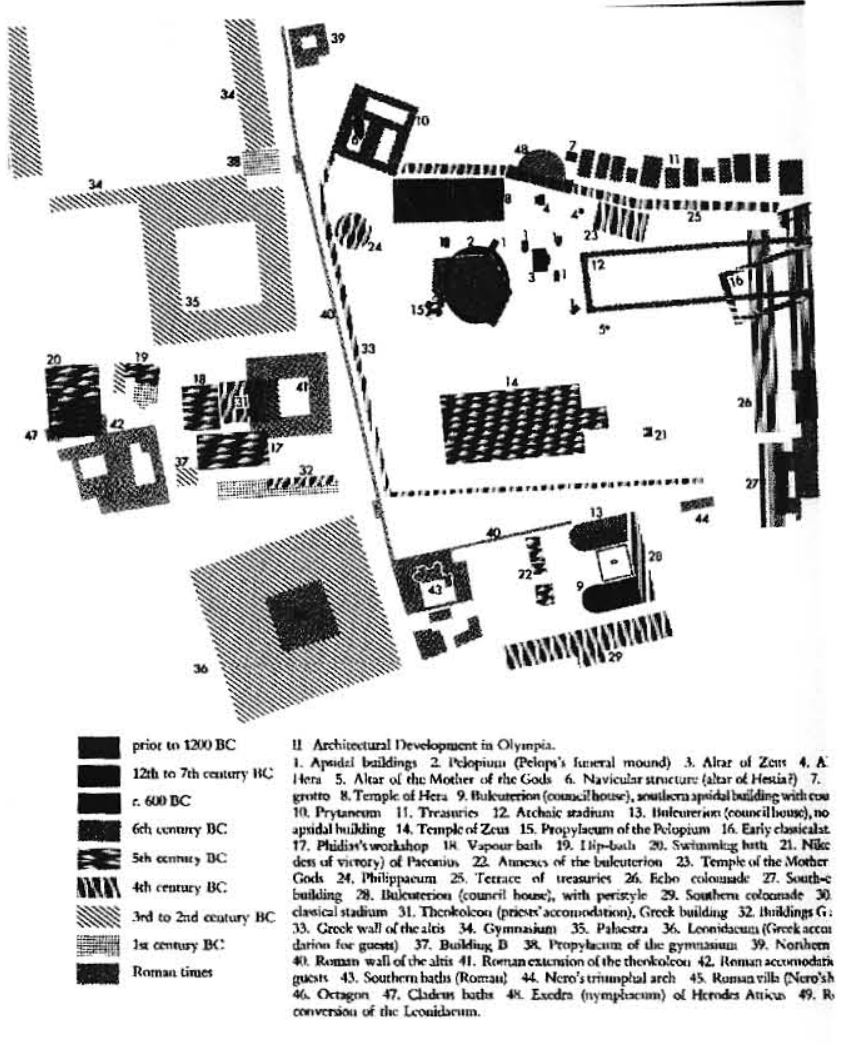

Figure 1. Map of the Altis at Olympia 


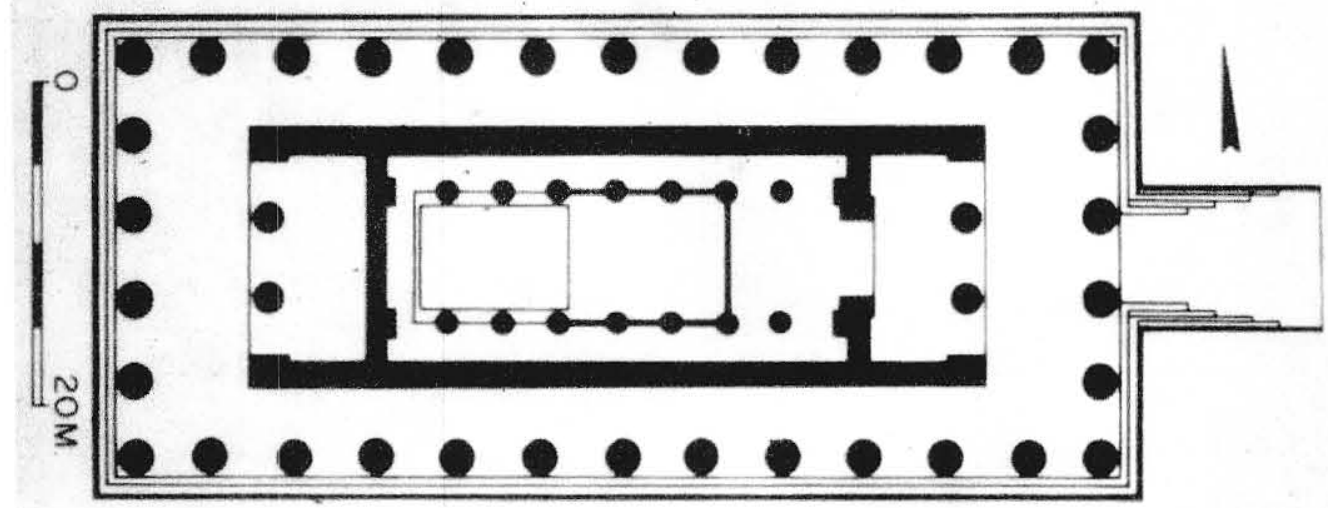

Figure 2. Plan of the Temple of Zeus at Olympia 


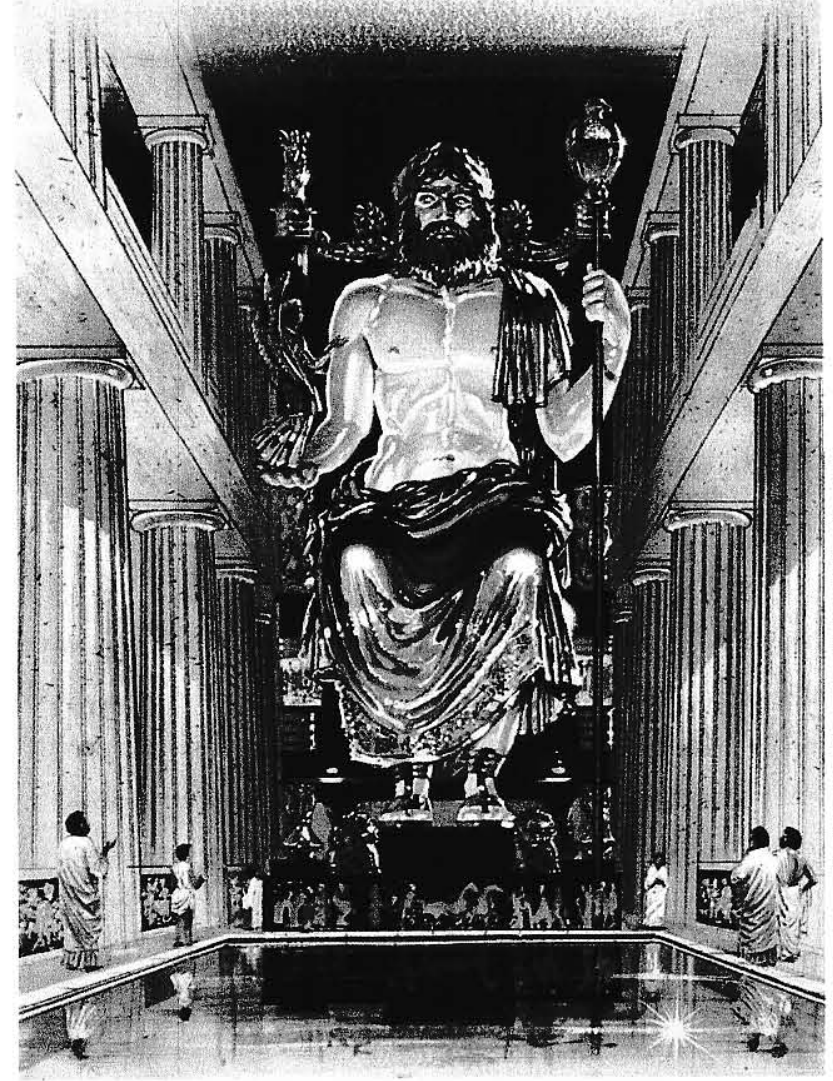

Figure 3. Colossal Statue of Zeus in Temple of Zeus 

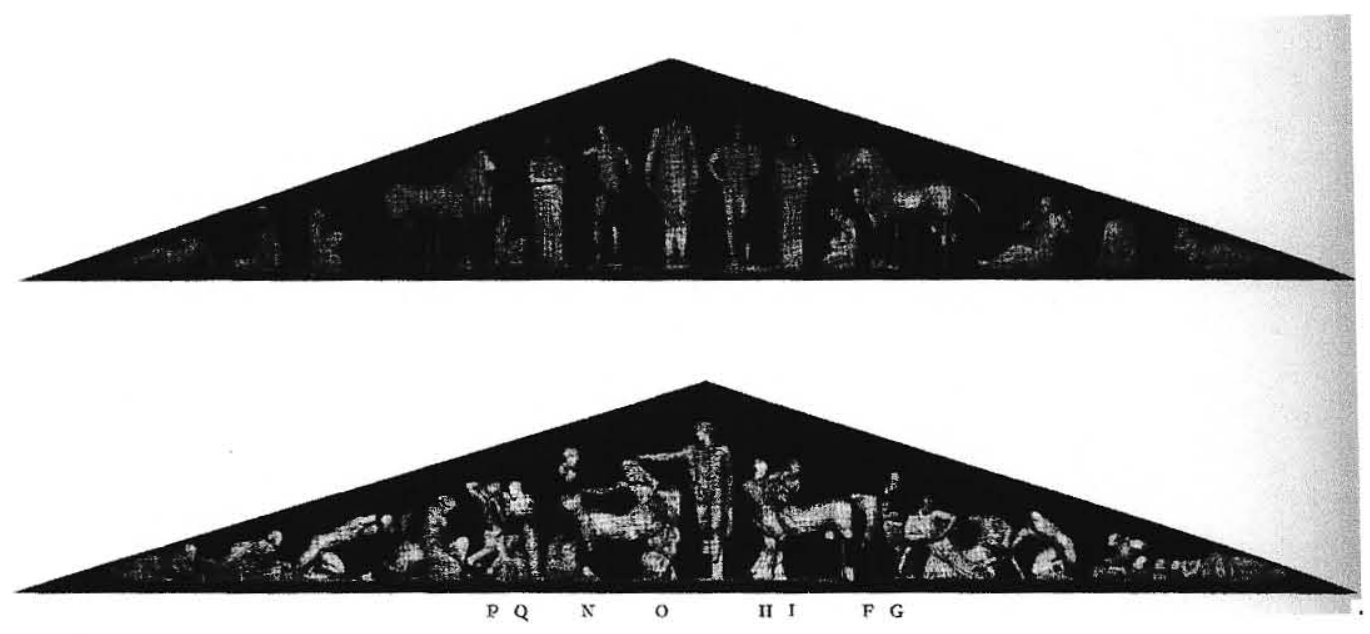

Figure 4. East and West Pediments of the Temple of Zeus 

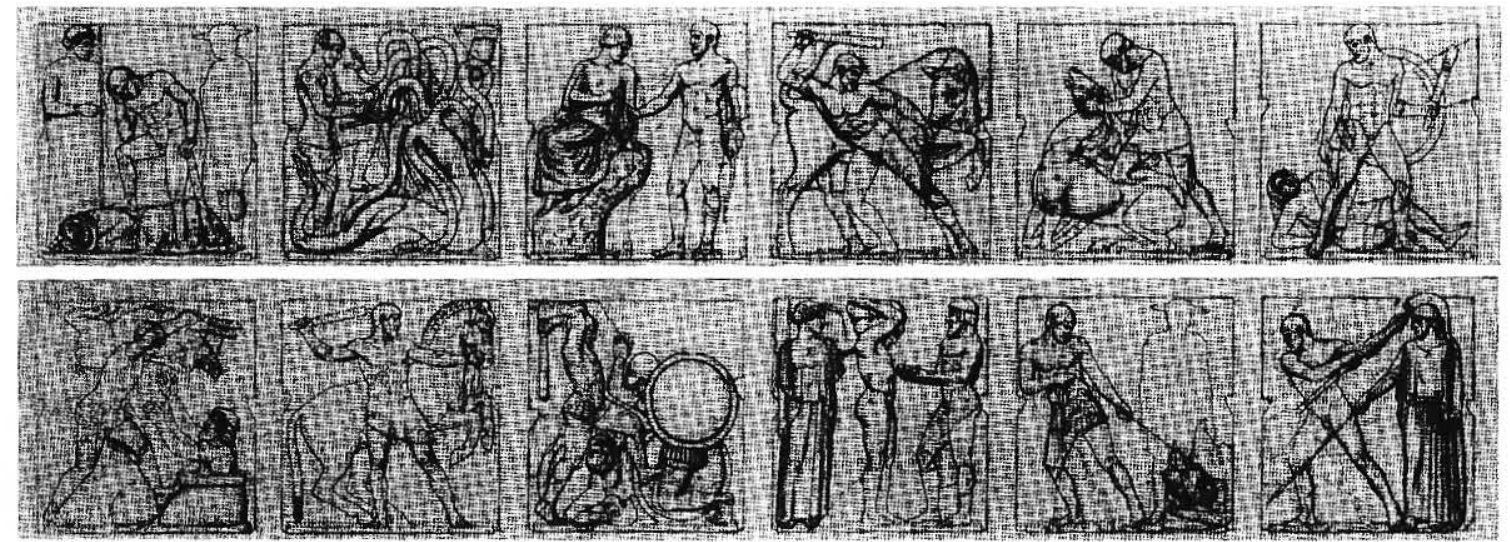

Figure 5. The twelve metopes from the Temple of Zeus 


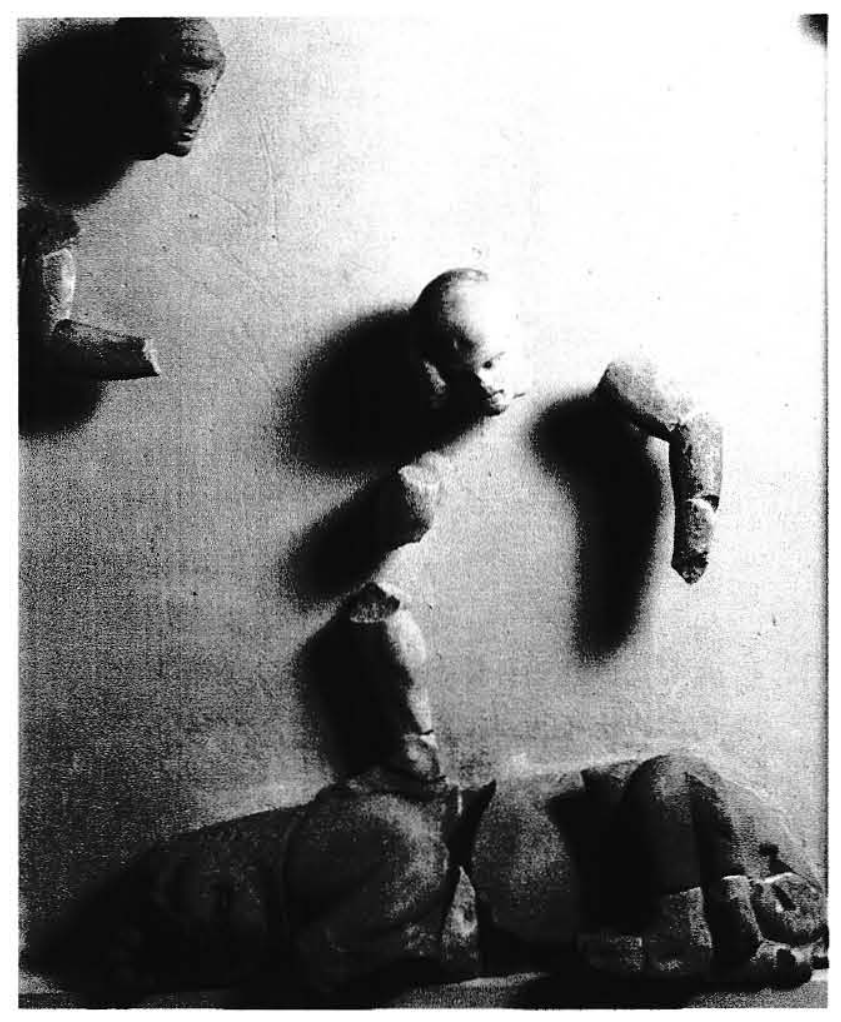

Figure 6. Nemean Lion Metope 


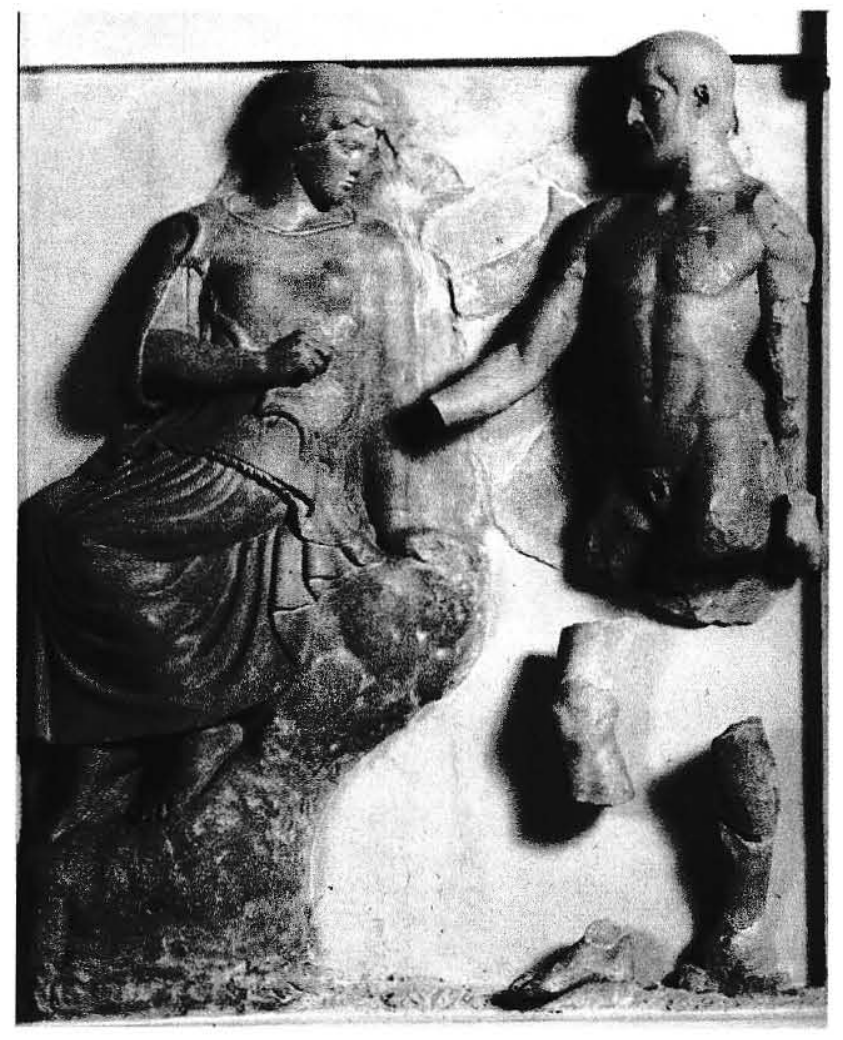

Figure 7. Stymphalian Birds Metope 


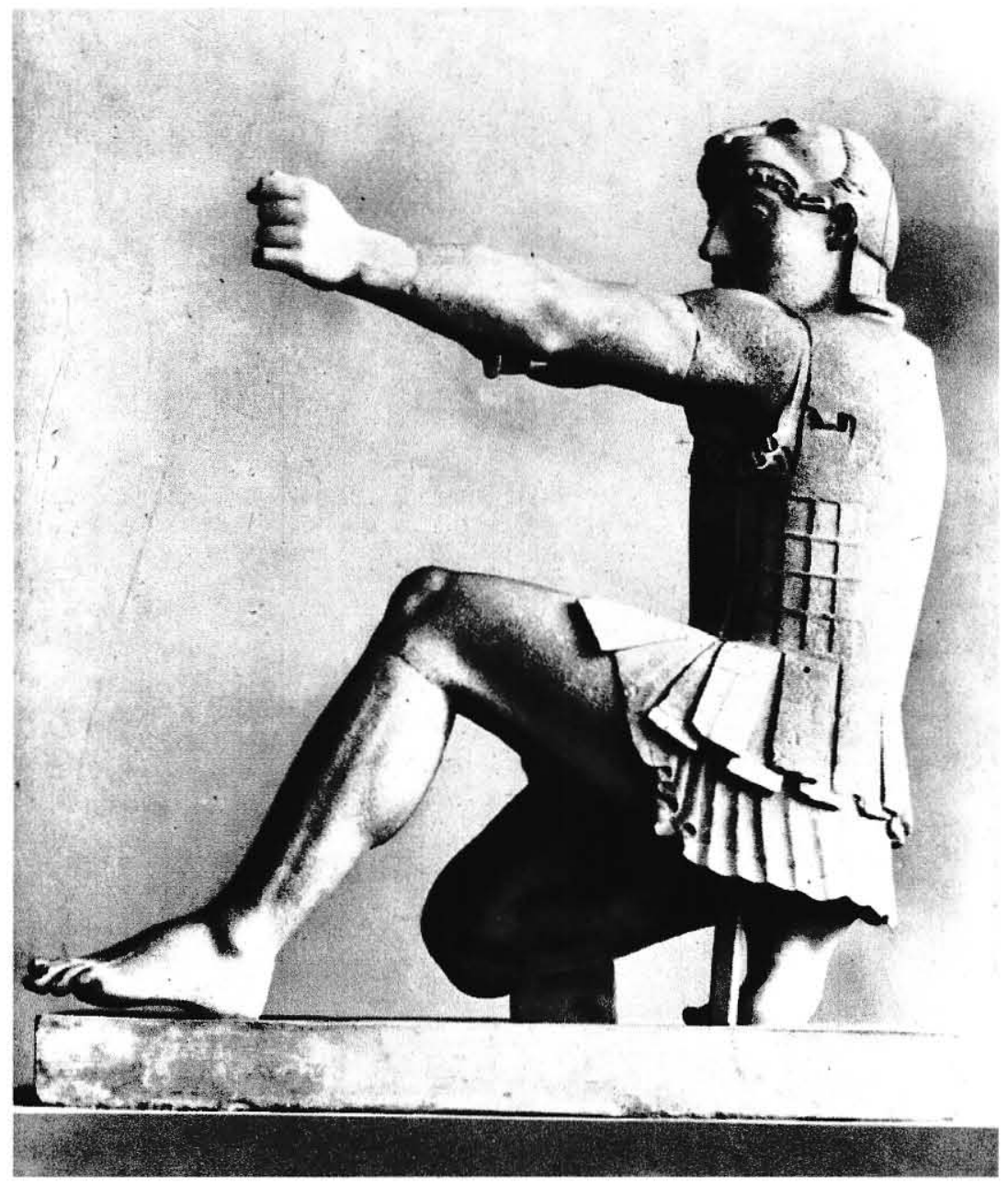

Figure 8. Herakles as an Archer on the Aphaia Temple at Aegina 


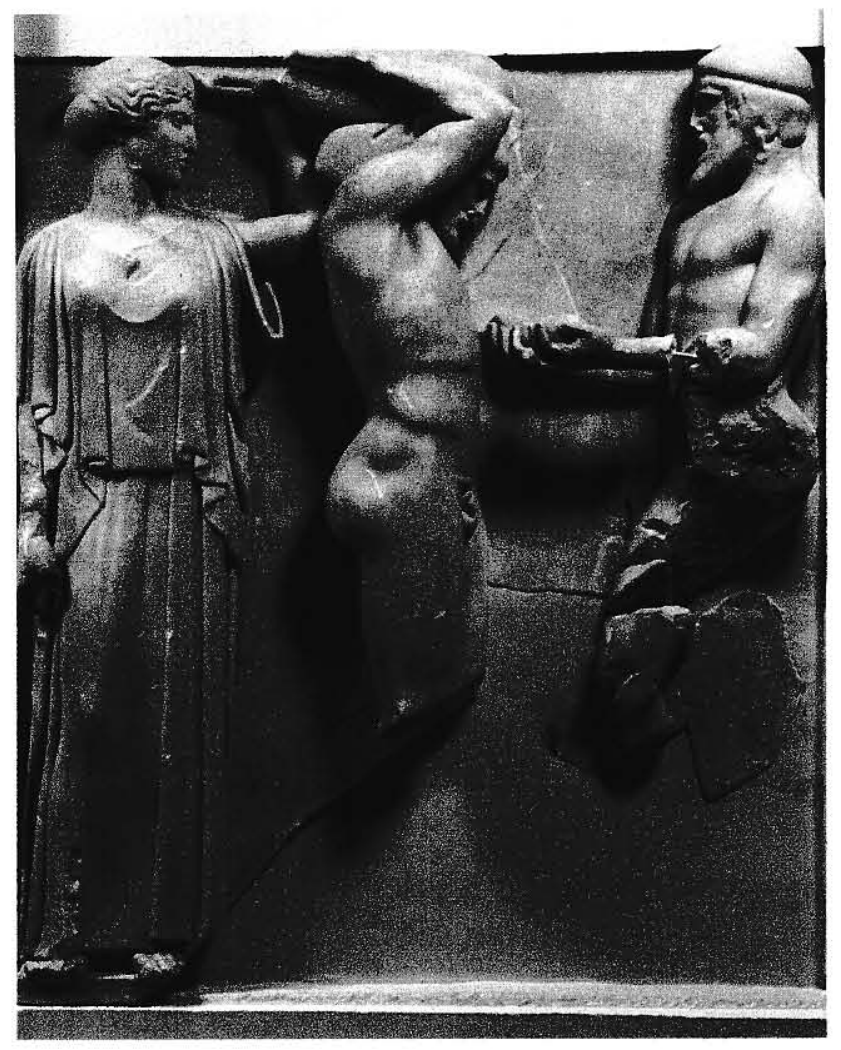

Figure 9. Apples of Hesperides Metope 


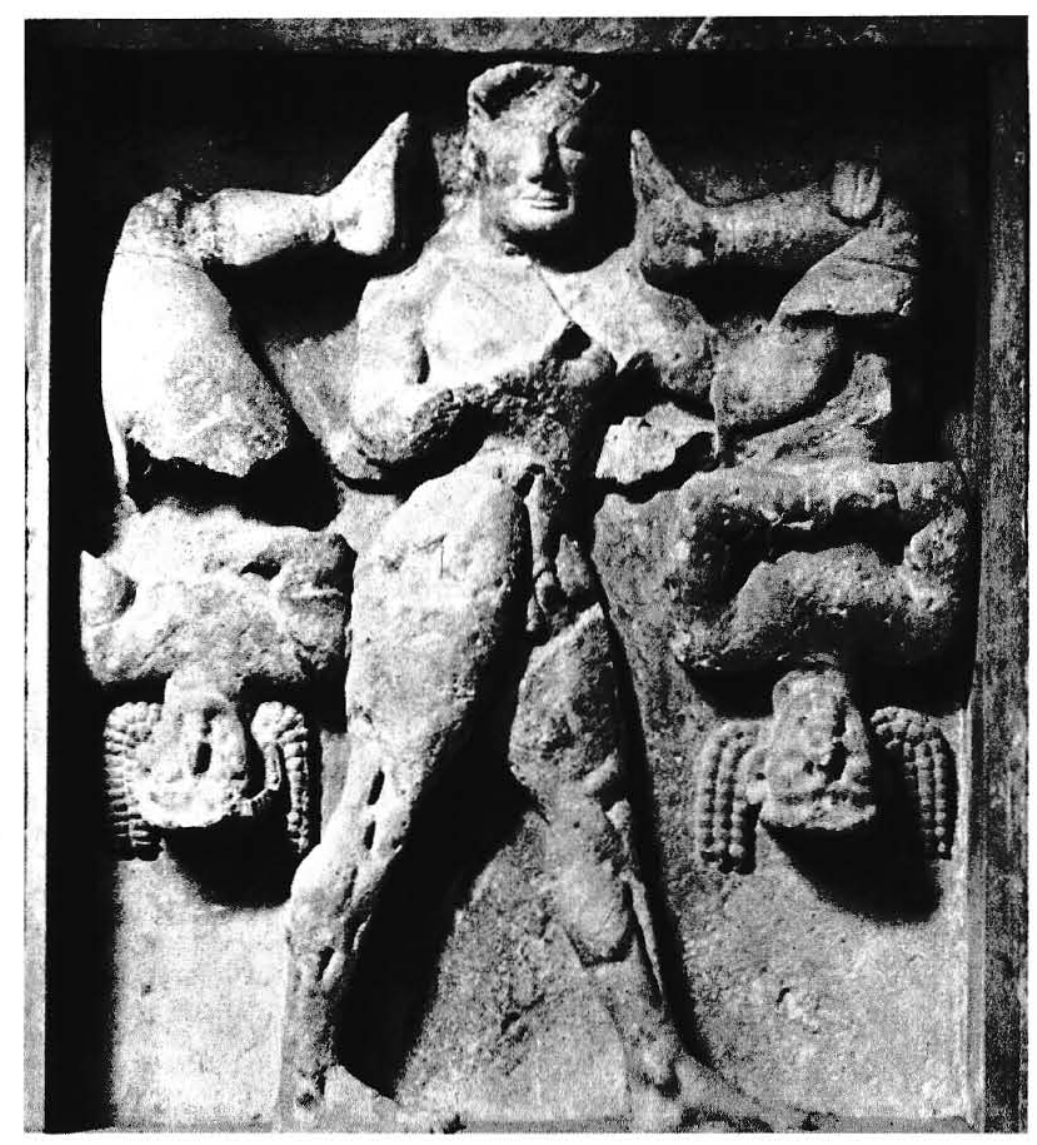

Figure 10. Metope of Herakles at Selinus on Temple C 


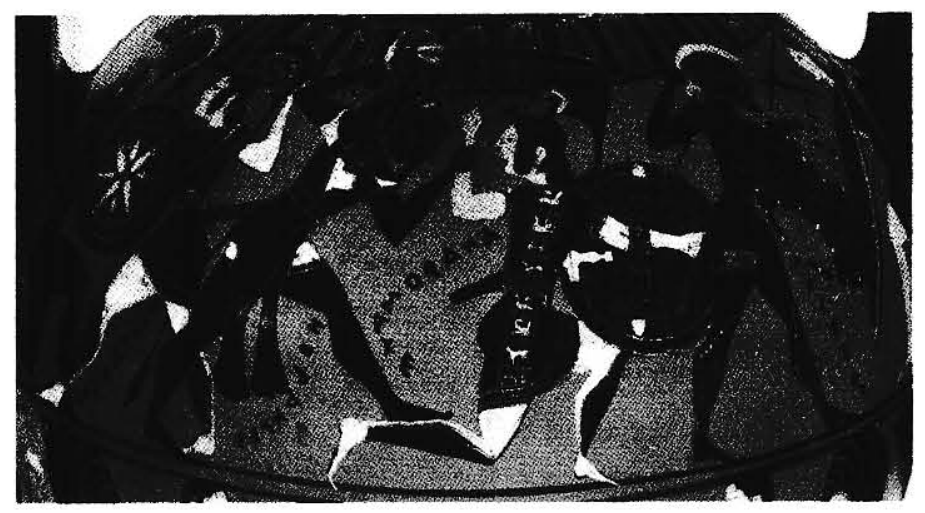

Figure 11. Attic Black-figure amphora from Vulci 


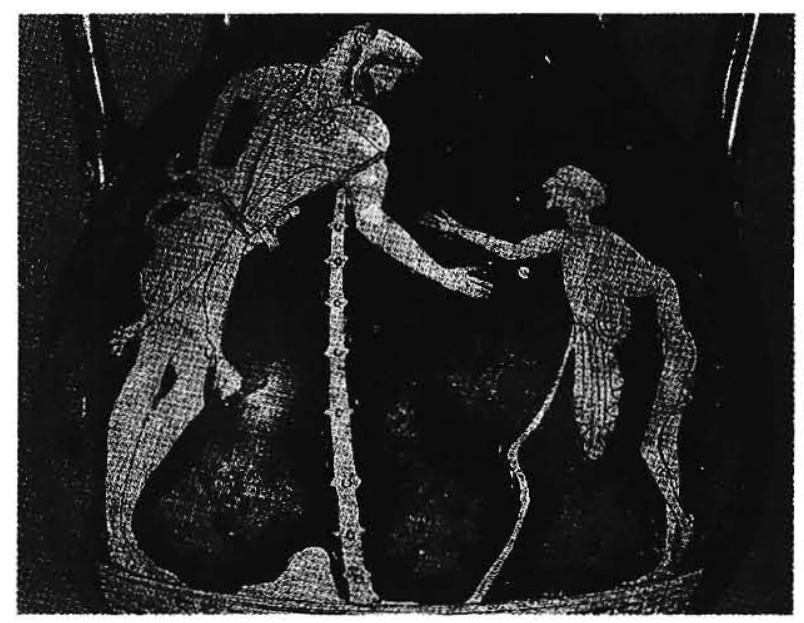

Figure 12. Attic Red-figure Pelike from Cerveteri 


\section{REFERENCES}

Abrahams, Ethel. Ancient Greek Dress. Chicago: Argonaut, Inc., 1964.

Anderson, William J. and R. Phene Spiers. The Architecture of Ancient Greece. AMS Press: New York, 1978.

Andronicos, Manolis. Olympia. Athens: Ekdotike Athenon S.A., 1995.

Ashmole, Bernard. Architect and Sculptor in Classical Greece. New York: New York University Press, 1972.

Boardman, John. Greek Art. New York: Frederick A. Praeger, 1964.

--. Greek Sculpture, The Classical Period. London: Thames and Hudson, 1985.

Burkert, Walter. Greek Religion. Cambridge: Harvard University Press, 1985.

Burstein, Stanley M., Walter Donlan, Sarah B. Pomeroy, and Jennifer Tolbert Roberts. Ancient Greece: A Political, Social, and Cultural History. New York: Oxford University Press, 1999.

Carpenter, T. H. Art and Myth in Ancient Greece. London: Thames and Hudson, 1991.

Cohen, Beth. "From Bowman to Clubman: Herakles and Olympia." Art Bulletin. December 1994.

Connolly, Peter. The Ancient City: Life in Classical Athens and Rome. Oxford: Oxford University Press, 1998.

Curtius, Ernst. Excavation of Olympia. New York: 1875.

Dinsmoor, William Bell. The Architecture of Ancient Greece. New York: Biblo and Tannen.

Drees, Ludwig. Olympia New York: Frederick A. Praeger, 1968.

Fullerton, Mark D. Greek Art. New York, Cambridge University Press: 2000. 
Galinsky, G. Karl. The Herakles Theme: The Adaptations of the Hero in Literature from Homer to the Twentieth Century. Rowman and Littlefield Publishers: Totowa, New Jersey, 1972.

Hurwitt, Jeffrey. The Athenian Acropolis. Cambridge, UK: Cambridge University Press, 1999.

Jansen, Anthony and H.W. History of Art. Upper Saddle River, New Jersey: PrenticeHall, Inc., 1991.

Lawrence, A.W. Greek Architecture. New Haven: Yale University Press, 1996.

Mikalson, Jon D. Athenian Popular Culture. Chapel Hill: The University of North Carolina Press, 1983.

Miller, Stephen G. Arete: Greek Sports from Ancient Sources. Los Angeles: University of California Press, 1991.

(Morford)Lenardon, Robert J. and Mark P.O. Morford. Classical Mythology. New York: Longman, 1985.

Osborne, Robin. Archaic \& Classical Greek Art. New York: Oxford University Press, 1998.

Pausanias, Guide to Greece. Middlesex, England: Penguin Books, 1971.

Pollitt, J.J. Art and Experience in Classical Greece. Cambridge, Massachusetts: Cambridge University Press: 1972.

Rhodes, Robin Francis. Architecture and Meaning on the Athenian Acropolis. New York: Cambridge University Press, 1995.

Richter, Gisela M. A. The Sculpture \& Sculptors of the Greeks. New Haven: Yale University, 1970.

Ridgeway, Brunilde Sismondo. The Archaic Style in Greek Sculpture. Princeton, NJ: Princeton University Press, 1977.

---. Fourth Century Styles in Greek Sculpture. Madison, Wisconsin: University of Wisconsin Press, 1997.

--. Fifth Century Styles in Greek Sculpture. Princeton, New Jersey: Princeton University Press, 1981.

Schobel, Heinz. The Ancient Olympic Games. Princeton, NJ: D. Van Nostrand Comp, Inc., 1965. 
Scully, Vincent. The Earth, The Temple, and the Gods. New Haven: Yale University Press, 1979.

Spivy, Nigel. Greek Art. London: Phaidon Press Limited, 1997.

Stewart, Andrew. Greek Sculpture: An Exploration. London: Yale University Press, 1990.

Stowsbury-O'Donnell, Mark D. Pictorial Narrative in Ancient Greek Art. New York: Cambridge University Press, 1999.

Swaddling, Judith. The Ancient Olympic Games. Austin: University of Texas Press, 1999.

Ulhenbrock, Jaimee Pugliese. Herakles Passage of the Hero Through Thousand Years of Classical Art. New Rochelle, New York: Aristide D. Caratzas, 1986.

Vollkommer, Rainer. Herakles in the Art of Classical Greece. Oxford: Oxford University Committee for Archaeology, 1988.

Yalouris, Athanasia, and Nicolaos Yalouris. Olympia: The Museum \&The Sanctuary. Athens: Ekdotike Athenon S.A., 1991.

Yalouris, Nicolaos. The Olympic Games in Ancient Greece. Athens: Ekdotike Athenon S.A., 1982. 


\section{CURRICULUM VITAE}

NAME:

Amanda Beth Crecelius Ott

ADDRESS: $\quad 504$ Davis Drive

Franklin, Indiana 46131

DOB:

New Albany, Indiana - June 3, 1980

EDUCATION

\& TRAINING: $\quad$ B.A., Painting \& Art History

Hanover College

1998-2002

M.A., Art History

University of Louisville

2002-2004

AWARDS: $\quad$ Allen R. Hite Assistantship at the University of Louisville 2002-2004 